University of Nebraska - Lincoln

DigitalCommons@University of Nebraska - Lincoln

2008

\title{
Variability in soil respiration across riparian-hillslope transitions
}

Vincent J. Pacific

vincent.pacific@myportal.montana.edu

Brian L. McGlynn

bmcglynn@montana.edu

Diego Andrés Riveros-Iregui

University of Nebraska - Lincoln, driveros2@unl.edu

Daniel L. Welsch

Howard E. Epstein

hee2b@virginia.edu

Follow this and additional works at: https://digitalcommons.unl.edu/natrespapers

Part of the Natural Resources and Conservation Commons

Pacific, Vincent J.; McGlynn, Brian L.; Riveros-Iregui, Diego Andrés; Welsch, Daniel L.; and Epstein, Howard E., "Variability in soil respiration across riparian-hillslope transitions" (2008). Papers in Natural Resources. 268.

https://digitalcommons.unl.edu/natrespapers/268

This Article is brought to you for free and open access by the Natural Resources, School of at DigitalCommons@University of Nebraska - Lincoln. It has been accepted for inclusion in Papers in Natural Resources by an authorized administrator of DigitalCommons@University of Nebraska - Lincoln. 
Published in Biogeochemistry 91 (2008), pp. 51-70; doi: 10.1007/s10533-008-9258-8

Copyright ( 2008 Springer Science+Business Media B.V. Used by permission.

Submitted May 9, 2008; accepted October 17, 2008; published online November 4, 2008.

\title{
Variability in soil respiration across riparian-hillslope transitions
}

\author{
Vincent J. Pacific, ${ }^{1}$ Brian L. McGlynn, ${ }^{1}$ Diego A. Riveros-Iregui, ${ }^{1}$ \\ Daniel L. Welsch, ${ }^{2}$ and Howard E. Epstein ${ }^{3}$
}

1. Department of Land Resources and Environmental Sciences, Montana State University, 334 Leon Johnson Hall, Bozeman, MT 59717, USA

2. Canaan Valley Institute, P.O. Box 673, Davis, WV, USA

3. Department of Environmental Sciences, University of Virginia, Clark 211, Charlottesville, VA 22904, USA

Corresponding author - Brian L. McGlynn, email bmcglynn@montana.edu

\begin{abstract}
The spatial and temporal controls on soil $\mathrm{CO}_{2}$ production and surface $\mathrm{CO}_{2}$ efflux have been identified as outstanding gaps in our understanding of carbon cycling. We investigated both across two riparian-hillslope transitions in a subalpine catchment, northern Rocky Mountains, Montana. Riparian-hillslope transitions provide ideal locations for investigating the controls on soil $\mathrm{CO}_{2}$ dynamics due to strong, natural gradients in the factors driving respiration, including soil water content (SWC) and soil temperature. We measured soil air $\mathrm{CO}_{2}$ concentrations (20 and $50 \mathrm{~cm}$ ), surface $\mathrm{CO}_{2}$ efflux, soil temperature, and SWC at eight locations. We investigated (1) how soil $\mathrm{CO}_{2}$ concentrations differed within and between landscape positions; (2) how the timing of peak soil $\mathrm{CO}_{2}$ concentrations varied across riparian and hillslope zones; and (3) whether higher soil $\mathrm{CO}_{2}$ concentrations necessarily resulted in higher efflux (i.e. did surface $\mathrm{CO}_{2}$ efflux follow patterns of subsurface $\mathrm{CO}_{2}$ ) ? Soil $\mathrm{CO}_{2}$ concentrations were significantly higher in the riparian zones, likely due to higher SWC. The timing of peak soil $\mathrm{CO}_{2}$ concentrations also differed between riparian and hillslope zones, with highest hillslope concentrations near peak snowmelt and highest riparian concentrations during the late summer and early fall. Surface $\mathrm{CO}_{2}$ efflux was relatively
\end{abstract}

homogeneous at monthly timescales as a result of different combinations of soil $\mathrm{CO}_{2}$ production and transport, which led to equifinality in efflux across the transects. However, efflux was $57 \%$ higher in the riparian zones when integrated to cumulative growing season efflux, and suggests higher riparian soil $\mathrm{CO}_{2}$ production.

Keywords: $\mathrm{CO}_{2}$, carbon dioxide, efflux, gas diffusion, hillslope, riparian

\section{Introduction}

Soil respiration is widely understood as the sum of root respiration (autotrophic) and microbial (heterotrophic) decomposition of soil organic matter (SOM), and is an important part of the global carbon cycle (Raich and Schlesinger 1992; Raich and Potter 1995; Risk et al. 2002a). Variability of soil respiration has been the focus of many studies, yet most were limited to short temporal (Kang et al. 2003, 2006; Sjogersten et al. 2006) or spatial (Fang et al. 1998; Musselman et al. 2005; Baldocchi et al. 
2006) scales within relatively homogeneous terrain. While these studies have provided essential knowledge on primary controls on soil respiration, little can be inferred about the variability of these controls across natural environmental gradients imposed by topography in complex terrain.

Gas-filled soil pores typically contain 10-100 times the concentration of atmospheric $\mathrm{CO}_{2}$ (Welles et al. 2001). In the standing paradigm of soil water content (SWC)-temperature- $\mathrm{CO}_{2}$ relationships, soil temperature is considered to be the primary control and SWC the secondary control on soil $\mathrm{CO}_{2}$ production (defined as the combination of heterotrophic and autotrophic respiration) (Raich and Schlesinger 1992; Raich and Potter 1995; Risk et al. 2002a). However, SWC can become the dominant control on soil $\mathrm{CO}_{2}$ production in very wet (Happell and Chanton 1993; Buchmann et al. 1997, 1998; Welsch and Hornberger 2004) or dry (Conant et al. 1998, 2004; McLain and Martens 2006; Riveros-Iregui et al. 2007) environments due to oxygen limitations (Skopp et al. 1990) and moisture stress (Orchard and Cook 1983), respectively. It is generally understood that increases in soil temperature (Hamada and Tanaka 2001; Raich et al. 2002; Pendall et al. 2004) and SWC (Davidson et al. 2000; Kelliher et al. 2004) promote higher rates of soil respiration, however, the switch from temperature to SWC as the primary control of soil $\mathrm{CO}_{2}$ production remains poorly understood.

The drivers of soil respiration can be spatially variable, partially in response to topographic position. For example, soil temperature is often dependent upon aspect, with southern aspects receiving more solar radiation than northern aspects (in the northern hemisphere) (Kang et al. 2006). SWC can vary across the landscape (Grayson and Western 2001; McGlynn et al. 2002; Kang et al. 2004; Wilson et al. 2005), with convergent areas, especially those in riparian zones, often having higher SWC and more sustained water tables (Beven and Kirkby 1979; Pennock et al. 1987; McGlynn and Seibert 2003). Riparian areas generally have a greater accumulation of SOM than hillslopes because frequent saturation retards microbial decomposition (Schlesinger 1997; Oades 1988; Sjogersten et al. 2006). Given the large variability in the drivers of respiration imposed by topography, thorough process understanding is necessary to determine the relative controls of soil $\mathrm{CO}_{2}$ concentrations and surface $\mathrm{CO}_{2}$ efflux across landscape positions.
A common misconception is that soil surface $\mathrm{CO}_{2}$ efflux can serve as a surrogate for soil $\mathrm{CO}_{2}$ production (i.e. higher efflux is the result of higher production). At long timescales (seasonal) production and efflux are likely equivalent, however at shorter timescales (hours to days) differences can result from changes in $\mathrm{CO}_{2}$ stores in the soil. These include changes in concentrations, water-filled pore space, or change of $\mathrm{CO}_{2}$ from gaseous to liquid phase (Risk et al. 2002b). Efflux is not only a function of production, but also of transport (Hamada and Tanaka 2001; Risk et al. 2002b; Riveros-Iregui et al. 2007), which is controlled by SWC and static soil properties such as porosity, connectivity, and tortuosity of pore spaces (Moldrup et al. 2001; Hillel 2004). SWC impacts gas transport (Millington 1959; McCarthy and Johnson 1995; Moldrup et al. 2000), as increases in the water-filled pore space greatly limit soil gas diffusivity (Washington et al. 1994; Davidson and Trumbore 1995; Moldrup et al. 2004). Thus, studies of soil respiration should examine both soil $\mathrm{CO}_{2}$ production and transport, because similar efflux, or "efflux equifinality" (comparable efflux with different combinations of the variables) at short timescales could be a result of different combinations of soil $\mathrm{CO}_{2}$ production and changing $\mathrm{CO}_{2}$ stores in the soil.

In this study we present measurements of soil $\mathrm{CO}_{2}$ concentrations and surface efflux along two riparian-hillslope transitions in a subalpine catchment characteristic of the northern Rocky Mountains. We investigated the natural variability of both $\mathrm{CO}_{2}$ concentrations and efflux in response to topographically controlled gradients of soil temperature and SWC to answer the following questions:

1. How do soil $\mathrm{CO}_{2}$ concentrations and surface $\mathrm{CO}_{2}$ efflux differ within and between landscape positions through time?

2. Do higher soil $\mathrm{CO}_{2}$ concentrations necessarily result in higher efflux (i.e. does surface $\mathrm{CO}_{2}$ efflux follow patterns of subsurface $\mathrm{CO}_{2}$ )?

\section{Materials and methods}

\section{Site description}

This study was conducted in the upper-Stringer Creek Watershed, a subcatchment of Tenderfoot 
Figure 1. a) Location of the Tenderfoot Creek Experimental Forest (within the Lewis and Clark National Forest), MT; b) LIDAR (ALSM) topographic image (resolution $<1 \mathrm{~m}$ for bare earth and vegetation) of the upper-Stringer Creek Watershed; and c transect location with measurement nest positions and riparian zone width.

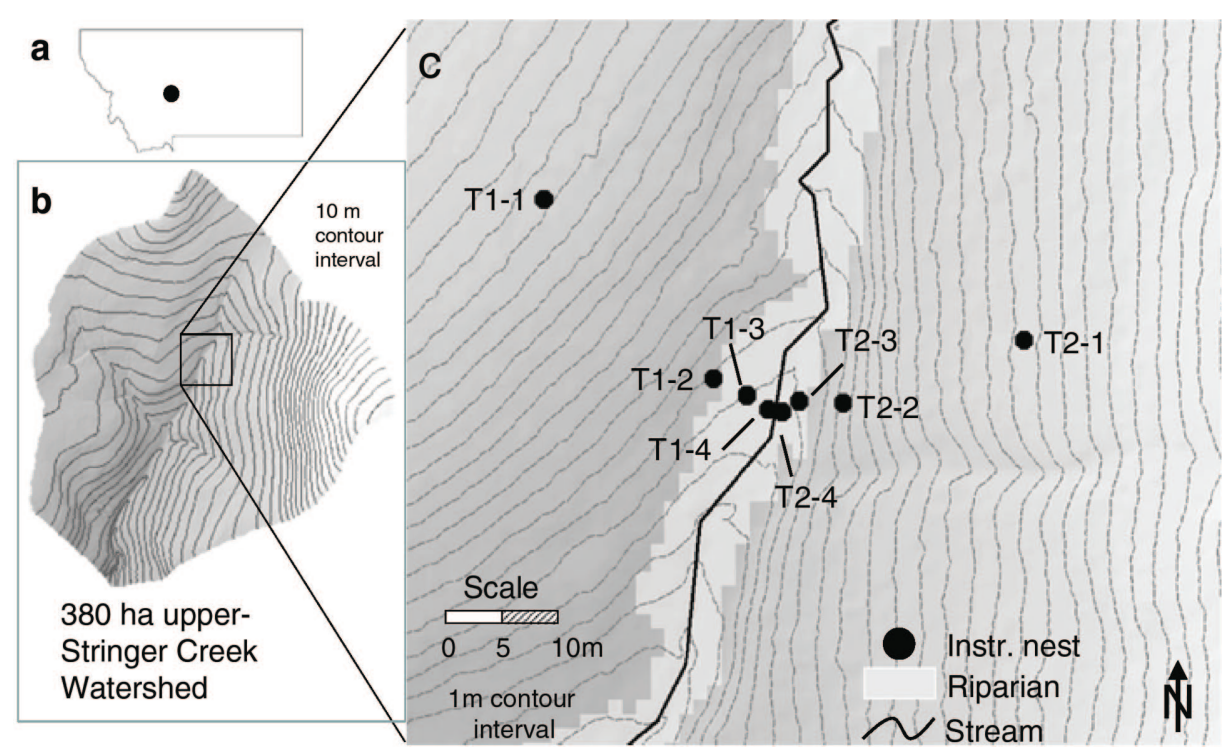

engelmannii), and whitebark pine (Pinus albicaulis). Tree heights average $15 \mathrm{~m}$ and leaf area index (LAI) values range from 2.8 to 3.2 (Woods et al. 2006).

The geology is characterized by granite gneiss, Wolsey shales, quartz porphyry, and Flathead quartzite (Farnes et al. 1995), and the most extensive soil types are loamy skeletal, mixed Typic Cryochrepts, and clayey, mixed Aquic Cryoboralfs (Holdorf 1981). Average soil carbon and nitrogen content at $20 \mathrm{~cm}$ is 2.3 and $0.17 \%$, respectively, in the riparian zones, and 2.7 and $0.11 \%$ in the hillslopes. At $50 \mathrm{~cm}$, average soil carbon and nitrogen content is 1.77 and $0.12 \%$, respectively, in the riparian zones, and 1.3 and $0.06 \%$ in the hillslopes. Average soil C:N ratios are 14.1 and 26.1 at $20 \mathrm{~cm}$ in the riparian and hillslopes zones, respectively, and 15.4 and 27.7 at $50 \mathrm{~cm}$. Soil bulk density is 0.962 and $0.911 \mathrm{~g} \mathrm{~cm}^{-3}$, in the riparian and hillslope zones, respectively, and soil root density is 11.5 and $9.6 \mathrm{~g}$ root $\mathrm{kg}^{-1}$ soil, respectively.

\section{Landscape characterization}

Two transects, each crossing one riparian-hillslope transition, were installed within the upper-Stringer Creek Watershed (Figure 1) in a subalpine watershed characteristic of the northern Rocky Mountains. The transects originate at Stringer Creek, which flows north to south, and extend up the fall line on both the west (Transect 1 ) and east (Transect 2) side of the creek approximately $50 \mathrm{~m}$ through the riparian and adjacent hillslope zones $(\sim 100 \mathrm{~m}$ total cies include subalpine fir (Abies lasiocarpa), Douglas fir (Pseudotsuga menziesii), Engelmann spruce (Picea 
across both transects). Transect 1 is characterized by a $12.7 \mathrm{~m}$ wide riparian zone of $\sim 5 \%$ slope and a convex hillslope ( $18 \%$ slope). Similarly, the riparian zone on Transect 2 is $11.8 \mathrm{~m}$ wide with a $\sim 5 \%$ slope, and a convex hillslope ( $14 \%$ slope). The transect locations were chosen because they are characteristic of riparian-hillslope transitions across the watershed and have median values of riparian zone width and slope.

Four instrumentation nests (two in the riparian zones, and two in the hillslopes) were installed along each transect. The riparian-hillslope transition was defined by a break in slope as well as change in vegetation (bluejoint reedgrass in the riparian zones and grouse whortleberry in the hillslopes). The nests were labeled 1-4, corresponding to their proximity to Stringer Creek, with 1 being the highest hillslope nest (furthest from the creek) (Figure 1). Gas wells were labeled " 20 " or " 50 ", corresponding to the 20 or $50 \mathrm{~cm}$ completion depth. Thus "T1-1-20" refers to the $20 \mathrm{~cm}$ gas well at the first nest location (most upslope) on Transect 1 . T2-3 is classified as a hillslope nest due to its soil properties, SWC, and water table dynamics.

\section{Environmental measurements}

We report measurements taken from February to October, 2005. To avoid time-of-day biases, data collection along the transect was conducted no earlier than $1000 \mathrm{~h}$ and no later than $1600 \mathrm{~h}$, as previous studies demonstrated that sampling between these times represents near-average daily surface $\mathrm{CO}_{2}$ efflux at this research site (Riveros-Iregui et al. 2007; in press). Sampling of all nests required $\sim 90 \mathrm{~min}$.

Measurements of soil temperature and SWC were collected within a $1 \mathrm{~m}^{2}$ measurement area at each nest location. Measurements were collected on 1-3 day intervals during the growing season, weekly during the fall and spring, and monthly during the winter. We defined the seasons based upon temperature thresholds and snow depth. Winter was defined as having an average snow depth greater than $0.5 \mathrm{~m}$ (November through midMay), and summer was defined as having average minimum daily temperatures above freezing (midJune through August). Fall (September and October) and spring (mid-May through mid-June) fell between the summer and winter criteria.
Soil temperature at $12 \mathrm{~cm}$ was measured manually at each nest with a soil thermometer $(12 \mathrm{~cm}$ soil thermometer, measurement range of -20 to $120^{\circ} \mathrm{C}$, Reotemp Instrument Corporation, San Diego, California, USA). Volumetric SWC $\left(\mathrm{cm}^{3} \mathrm{H}_{2} \mathrm{O} / \mathrm{cm}^{3}\right.$ soil) was measured manually at three locations (due to potential spatial variability of SWC) at each nest with a portable SWC meter that integrated over the upper $20 \mathrm{~cm}$ of soil (Hydrosense, Campbell Scientific Inc., Utah, USA). The three SWC measurements at each nest location were averaged for data analysis. Soil temperature and SWC measurements were not collected while snow was on the ground to minimize snowpack disturbance and associated soil $\mathrm{CO}_{2}$ dynamics.

A time domain reflectometry (TDR) system was developed in the lab following Robinson et al. (2003) to calibrate the Hydrosense portable SWC meter. The performance of the TDR sensor was tested in the laboratory over a wide range of SWC by comparing TDR and gravimetric measurements. To calibrate and test the Hydrosense, TDR-based SWC was measured in the field $(n=\sim 300)$ with both sensors over a wide range of SWC. SWC measurements by both instruments were comparable in the upland mineral soil $\left(r^{2}=0.99\right)$, but the Hydrosense overestimated SWC in the organic riparian soil. Hydrosense measurements in the organic riparian soil were therefore adjusted using the following equation:

$$
\begin{aligned}
\text { SWC }= & (0.7704 \times \text { Hydrosense measurement }) \\
& +0.8774 \quad\left(r^{2}=0.986\right)
\end{aligned}
$$

Two snow survey telemetry (SNOTEL) stations within $2 \mathrm{~km}$ (Onion Park-2,259 m, and Stringer Creek $-1,996 \mathrm{~m}$ ) and a tipping-bucket rain gauge (TR-525 M, accurate to within 1\% for up to $50 \mathrm{~mm} / \mathrm{h}$, Texas Electronics, Dallas, TX, USA) located on T2 provided real-time data on snow depth, snow water equivalent, and rainfall. Snow depth and snow water equivalent from the Onion Park SNOTEL station were used for data analysis due to its similar elevation. SNOTEL measurements of snow depth were corroborated by monthly manual measurements at each nest location along the transects.

\section{Hydrologic measurements}

Groundwater wells screened from the completion depth $(0.5-2 \mathrm{~m})$ to within $0.2 \mathrm{~m}$ of the ground 
surface were installed at all riparian zone nests and the hillslope nest adjacent to the riparian-hillslope transition (i.e. T1-2, T1-3, T1-4, T2-2, T2-3, T2-4). Groundwater levels were recorded every 30 min using capacitance rods $( \pm 1 \mathrm{~mm}$ resolution, Trutrack, New Zealand).

\section{Soil $\mathrm{CO}_{2}$ concentration measurements}

At all nest locations, gas wells that equilibrate with the soil atmosphere were installed at the 20 and $50 \mathrm{~cm}$ depth (one gas well per depth per nest to minimize disturbance) following the methods described by Andrews and Schlesinger (2001) and Welsch and Hornberger (2004). The gas wells consisted of a $15-\mathrm{cm}$ section of $5.25 \mathrm{~cm}$ (inside diameter) PVC inserted into a hole augered to 20 or $50 \mathrm{~cm}$. The top of the PVC was capped with a rubber stopper (size 11) through which passed two pieces of PVC tubing (4.8 $\mathrm{mm}$ inside diameter Nalgene 180 clear PVC, Nalge Nunc International, Rochester, N.Y., USA) that extended above the ground surface. The tubing was joined with connectors (6-8 $\mathrm{mm}$ HDPE FisherBrand tubing connectors, Fisher Scientific, USA) to ensure that no gas escaped between measurements.

To measure soil air $\mathrm{CO}_{2}$ concentrations, the two sections of tubing from the gas well were attached to the IRGA, and the air from the gas well was circulated through the IRGA and returned to the gas well. This technique created a closed loop and minimized pressure changes during sampling (Andrews and Schlesinger 2001; Welsch and Hornberger 2004). When snow was present, soil $\mathrm{CO}_{2}$ concentrations were measured through $1 \mathrm{~m}$ tubing extenders attached to a $2 \mathrm{~m}$ post at each nest location prior to snowfall. Soil $\mathrm{CO}_{2}$ concentrations were not measured between July 18 and August 7, 2005 due to equipment malfunction.

Soil air $\mathrm{CO}_{2}$ concentrations were measured with portable infrared gas analyzers (IRGA) (model EGM-3, accurate to within 1\% of calibrated range [050,000 ppm]; PP Systems, Massachusetts, USA;) and (model GM70 with M170 pump and GMP $221 \mathrm{CO}_{2}$ probe, accurate to within $1 \%$ of calibrated range [050,000 ppm]; Vaisala, Finland). The instruments were routinely compared in the field to ensure measurements were within $1 \%$, and both instruments were recalibrated by the manufacturer three times during the duration of the study. Both instruments were al- lowed a 30 min warm-up time (per the manufacturer's recommendations), then remained on for the duration of measurement. Soil $\mathrm{CO}_{2}$ concentration measurements from the EGM-3 were internally corrected for air temperature and pressure. Measurements from the GMP 221 were compensated for air temperature and pressure following recommendations by the manufacturer and described in detail by Tang et al. (2003). Each soil $\mathrm{CO}_{2}$ concentration measurement required 2-5 $\mathrm{min}$ (recirculation time) before stabilized values were recorded. Recirculation time did not affect soil $\mathrm{CO}_{2}$ concentrations in our experimental design or similar designs (Andrews and Schlesinger 2001; Welsch and Hornberger 2004).

\section{Surface $\mathrm{CO}_{2}$ efflux measurements}

A surface $\mathrm{CO}_{2}$ efflux plot was selected at each nest location, consisting of a $0.5 \mathrm{~m}^{2}$ area roped off to minimize soil trampling. Vegetation within the efflux plot was clipped to minimize the effect of above-ground autotrophic respiration inside the chamber. Vegetation was clipped approximately once a week after a round of measurements was collected, and roots were left intact to minimize disturbance to belowground root respiration.

Three surface $\mathrm{CO}_{2}$ efflux measurements were collected from each plot on all sampling days using a soil respiration chamber (SRC-1 chamber with a footprint of $314.2 \mathrm{~cm}^{2}$, accurate to within $1 \%$ of calibrated range [0-9.99 $\left.\mathrm{g} \mathrm{CO}_{2} \mathrm{~m}^{-2} \mathrm{~h}^{-1}\right]$ in conjunction with an IRGA (EGM-4, accurate to within $1 \%$ of calibrated range [0-2,000 ppm]; PP Systems, Massachusetts, USA). Before each measurement, the chamber was flushed with ambient air for $15 \mathrm{~s}$ and then inserted $3 \mathrm{~cm}$ into the soil to ensure a good seal between the chamber and the ground surface. The sampling period lasted for $120 \mathrm{~s}$, or until the $\mathrm{CO}_{2}$ concentration inside the chamber increased by $60 \mathrm{ppm}$. To determine the $\mathrm{CO}_{2}$ efflux during the measurement, a quadratic equation was fitted to the relationship between the increasing $\mathrm{CO}_{2}$ concentration and elapsed time (per manufacturer's recommendation). We estimated cumulative growing season efflux from June 9 to August 31, 2005 by linearly interpolating between measurements collected every 2-7 days. Previous studies (Riveros-Iregui et al. in press) demonstrated that this was a robust approach for comparison of efflux measurements across multiple locations over extended periods of time. 
To collect efflux measurements from the snowpack, a snowshoe was constructed of fine metal screen attached to a $0.5 \mathrm{~m}^{2}$ PVC frame $(2.5 \mathrm{~cm}$ inside diameter PVC). A hole was cut into the screen to allow the base of the chamber to be inserted into the snowpack. The chamber was modified to extend its length (by $10 \mathrm{~cm}$ ) by attaching a metal ring (10 cm diameter) to its base to ensure a good seal with the snowpack. The snowshoe method has been found appropriate as it causes minimal disturbance to the snowpack (McDowell et al. 2000). Surface $\mathrm{CO}_{2}$ efflux measurements did not begin until the middle of April, 2005 due to equipment malfunction.

\section{Soil gas diffusivity}

Given the difficulty in accurately measuring in situ soil gas diffusivity without severely disturbing the soil, we estimated an "effective" diffusivity for the upper $20 \mathrm{~cm}$ of the soil profile. Soil gas diffusivity was inversely calculated using Fick's Law and measured values of soil $\mathrm{CO}_{2}$ concentrations at $20 \mathrm{~cm}$ and surface $\mathrm{CO}_{2}$ efflux (and an assumed atmosphere $\mathrm{CO}_{2}$ concentration of $400 \mathrm{ppm}$ ):

$$
F=-D \frac{\partial C}{\partial z}
$$

where $D$ is the diffusivity $\left(\mathrm{m}^{2} \mathrm{~s}^{-1}\right), \mathrm{C}$ is the $\mathrm{CO}_{2}$ concentration (ppm), and $z$ is the depth (m).

This approach provides an estimate of $D$ for each sampling time and allows for relative comparisons between riparian and hillslope zones.

Statistical analyses

Analysis of variance (ANOVA) statistics $(\alpha=0.05)$ were employed to test differences between riparian and hillslope soil $\mathrm{CO}_{2}$ concentrations, surface $\mathrm{CO}_{2}$ efflux, soil temperature, SWC, and soil gas diffusivity, with separate analyses for each month due to temporal dynamics at our research site. For these variables, $n=8$ from Feb through May as measurements were collected from eight nest locations one day each month during the winter (due to limited site access). During the growing season, $n$ ranged from 104 in June to 160 in July due to multiple sampling days each month, with measurements from eight nest locations on each sampling day. Three measurements of SWC and surface $\mathrm{CO}_{2}$ efflux were collected at each nest location on all sampling days to account for possible measurement error, then averaged for data analysis.

\section{Results}

Soil temperature

\section{Spatial variability}

Soil temperature $(12 \mathrm{~cm})$ was not significantly different between riparian and hillslope landscape positions (Table 1, Figures 2, 3, 4). Average soil temperature and standard deviation at riparian and hillslope nests were within 0.3 and $0.2^{\circ} \mathrm{C}$ of each, respectively. Aspect (west versus east) did not affect soil temperature at this study site (Figure 3).

\section{Temporal variability}

Near the middle of June, 2005, when soil temperature measurements began, soil temperatures ranged from 4 to $12^{\circ} \mathrm{C}$ (Figures $5 \& 6$ ), with the lowest soil temperatures under or near patches of snow on the hillslopes. Soil temperatures increased by $\sim 10^{\circ} \mathrm{C}$ by the beginning of August at most nest locations. A sharp decrease occurred near the middle of August, coincident with cool weather and periodic snow. Soil temperatures then decreased to below freezing by the end of September.

Soil water content

Spatial variability

SWC (integrated over top $20 \mathrm{~cm}$ ) was significantly different between riparian and hillslope zones $(p \ll 0.01$, Table 1$)$, with higher and more variable SWC in the riparian zones (Figure 3).

\section{Temporal variability}

In the middle of June, 2005, SWC was the highest during the period of measurement (June 12-October 1,2005$)$, reaching saturation at many riparian nest locations, but remaining below $40 \%$ in the hillslopes (Figure 4). High SWC in June corresponded to recent snowmelt (which peaked in the middle of May). SWC then decreased over the summer, with 
Table 1. Analysis of variance (ANOVA) statistics for riparian versus hillslope soil temperature, soil water content, soil gas diffusivity, surface $\mathrm{CO}_{2}$ efflux, and soil $\mathrm{CO}_{2}$ concentrations (20 and $50 \mathrm{~cm}$ ) from February 6 to September 30, 2005

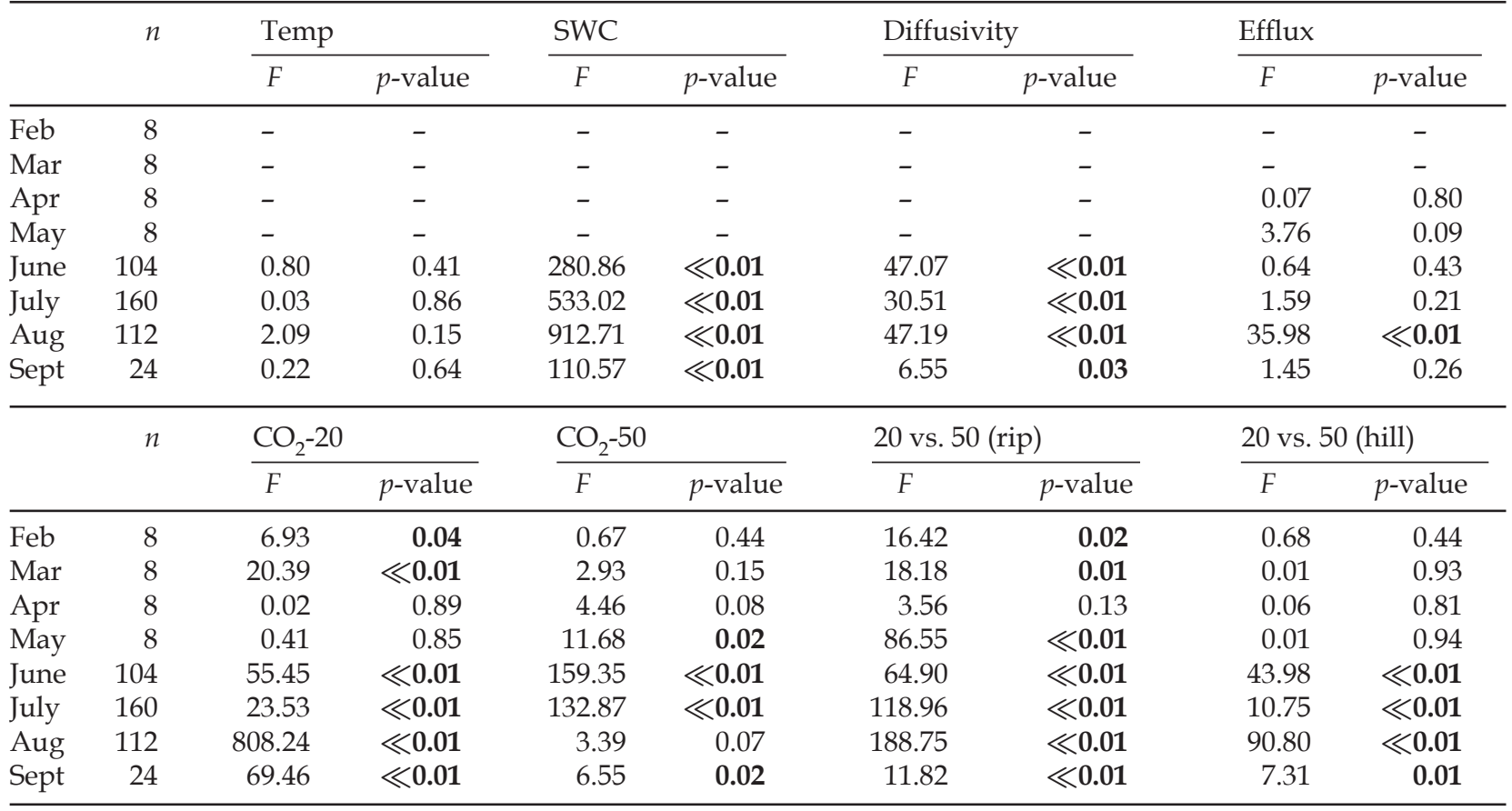

An a of 0.05 was used for all analyses. If no value is given, data was not collected during that time. Bold numbers indicate significant differences

the lowest values (5-10\%) in August and September in the hillslopes.

\section{Soil gas diffusivity}

Please note that these results give only a general indication of soil gas diffusivity as our calculations used soil $\mathrm{CO}_{2}$ concentrations at $20 \mathrm{~cm}$ and therefore do not account for near-surface soil $\mathrm{CO}_{2}$ production.

\section{Spatial variability}

Soil gas diffusivity was significantly higher in the hillslope zones $(p<0.05$, Table 1; Figures $3 \& 4)$.

\section{Temporal variability}

Soil gas diffusivity generally increased from June through September in the hillslopes, with relatively less change in the riparian zones (Figures 5 \& 6).
Snow depth, snow water equivalent, and rainfall

Snow depth and snow water equivalent (SWE) increased over the winter, with April maxima of 126 and $46 \mathrm{~cm}$, respectively, and complete snowmelt by the middle of June (Figures 5 \& 6). Manual measurements of snow depth at each nest location corroborated snow data from the Onion Park SNOTEL site. While heterogeneity in snow depth was observed across the transect, there was little variation between snow depth in the riparian and hillslope zones when the data was averaged within each landscape element. Rainfall varied from May to October, with the largest precipitation events during July (Figures 5 \& 6).

\section{Groundwater levels}

Peak snowmelt occurred on June 11, 2005. The groundwater table rose to the near-ground surface at all riparian nests during snowmelt, but rarely rose above the well completion depths (1-2 m) in 
Figure 2. Bivariate plots of soil temperature and soil $\mathrm{CO}_{2}$ concentration in a) hillslope zones, $20 \mathrm{~cm}, \mathbf{b}$ ) riparian zones, $20 \mathrm{~cm}, \mathrm{c}$ ) hillslope zones, $50 \mathrm{~cm}$, and d) riparian zones, $50 \mathrm{~cm}$; soil water content (SWC) and $20 \mathrm{~cm}$ soil $\mathrm{CO}_{2}$ concentration in e) hillslope zones and f) riparian zones; SWC and surface $\mathrm{CO}_{2}$ efflux in $\mathbf{g}$ ) hillslope zones and $\mathbf{h}$ ) riparian zones; and soil $\mathrm{CO}_{2}$ concentration and surface $\mathrm{CO}_{2}$ efflux in i) hillslope zones, and j) riparian zones from February 6 to October 1, 2005. Filled symbols denote landscape positions closer to Stringer Creek for both riparian and hillslope zones. Y-axis for surface $\mathrm{CO}_{2}$ efflux is presented in both $\mathrm{g} \mathrm{CO}_{2} \mathrm{~m}^{-2} \mathrm{~h}^{-1}$ and $\mu \mathrm{mol}$ $\mathrm{CO}_{2} \mathrm{~m}^{-2} \mathrm{~s}^{-1}$ to aid in comparison to other studies.
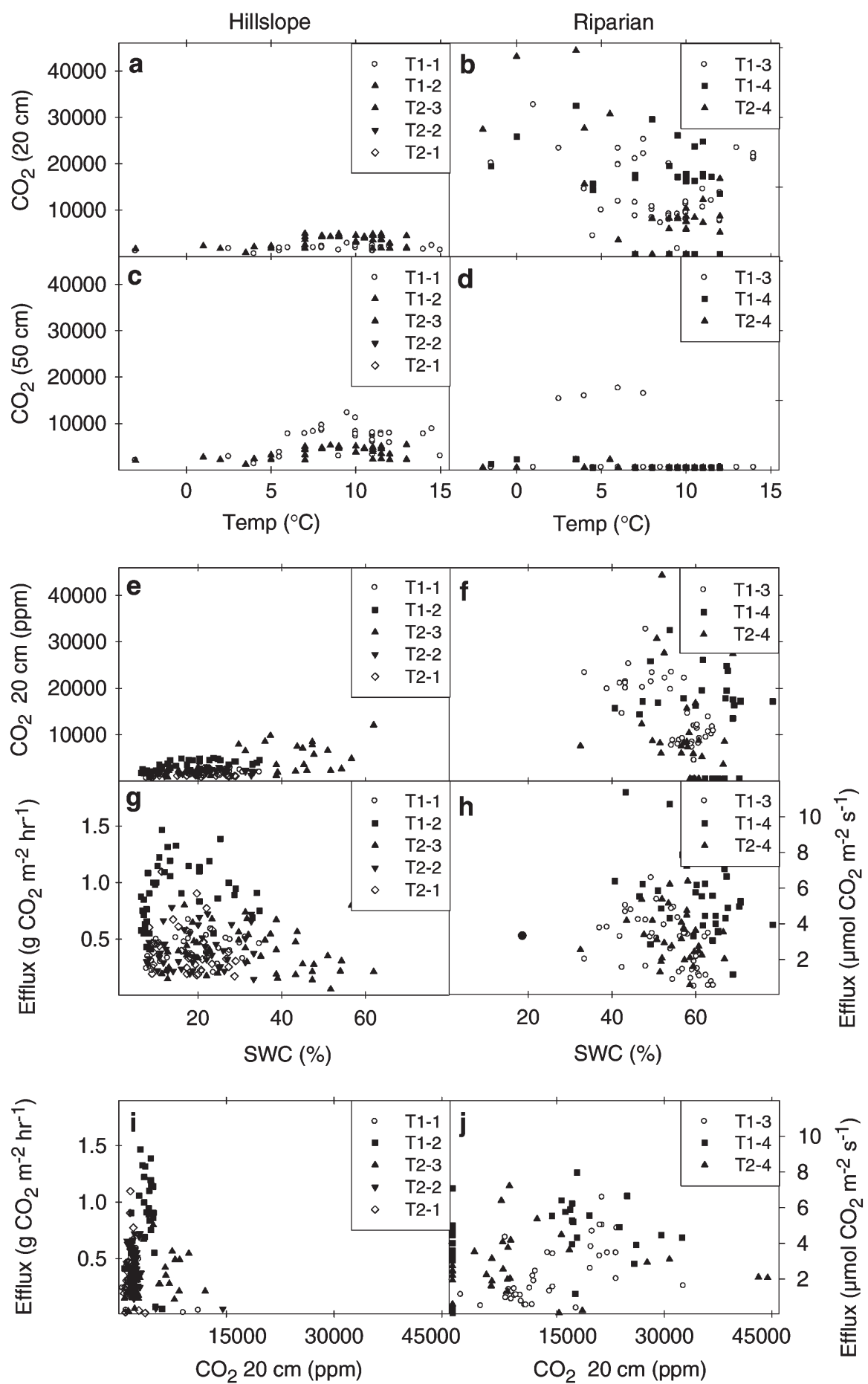

the hillslopes during the extent of this study (unpublished data). The groundwater table declined over the summer, except during a series of high precipitation events near the end of June, at which point the groundwater table rose $\sim 5-10 \mathrm{~cm}$ at all riparian nests. By late summer or early fall, the groundwater table declined below $50 \mathrm{~cm}$ from the ground surface at all riparian nests. Figure 7 presents water table data from T1-4, which was characteristic of other riparian zone groundwater wells. 
Figure 3. Box-plots of riparian and hillslope zone a) soil water content; b) soil temperature; $\mathbf{c}$ ) soil gas diffusivity; d) soil $\mathrm{CO}_{2}$ concentration $-20 \mathrm{~cm}$; e) soil $\mathrm{CO}_{2}$ concentration $-50 \mathrm{~cm}$; and f) surface $\mathrm{CO}_{2}$ efflux from February 6 to October 1, 2005. Boxes represent the inter-quartile range, the lines the medians, and the whiskers the 10th and 90 th percentiles.

Soil $\mathrm{CO}_{2}$ concentrations

\section{Spatial variability}

In general, soil $\mathrm{CO}_{2}$ concentrations were significantly higher in the riparian zones (Table 1) and often exceeded 20,000 ppm at $20 \mathrm{~cm}$, while hillslope soil $\mathrm{CO}_{2}$ concentrations generally remained below 5,000 ppm (Figures $3 \& 4$ ). There were also significant differences between 20 and $50 \mathrm{~cm}$ soil $\mathrm{CO}_{2}$ concentrations in both the riparian (higher at $20 \mathrm{~cm}$ ) and hillslope (higher at $50 \mathrm{~cm}$ ) zones (Table 1, Figure 8$)$, with the greatest differences in the riparian zones. The magnitude of the difference between 20 and $50 \mathrm{~cm}$ riparian soil $\mathrm{CO}_{2}$ concentrations generally increased from summer to fall (Figure 5). In contrast to the riparian zones, the magnitude of the difference in hillslope soil $\mathrm{CO}_{2}$ concentrations by depth decreased from summer to fall (Figure 6).

\section{Seasonal variability: winter-to-spring}

There was a high degree of seasonal variability in soil $\mathrm{CO}_{2}$ concentrations in both riparian and hillslope zones (Figures $5 \& 6$ ), with peaks occurring during both winter and summer. Riparian soil $\mathrm{CO}_{2}$ concentrations increased over the winter (Figure 5), with a winter peak of approximately 20,000 ppm between the middle of March and the middle of April, 2005. In contrast, the hillslope zones peaked at approximately 10,000 ppm between the middle of April and middle of May (Figure 6), which were the highest hillslope concentrations measured during this study.

\section{Seasonal variability: summer-to-fall}

There were also temporal differences in summerto-fall peaks in soil $\mathrm{CO}_{2}$ concentrations between the riparian and hillslope zones. Peaks in riparian zone soil $\mathrm{CO}_{2}$ concentrations (average values of $\sim 30,000 \mathrm{ppm}$ ) occurred during September, 2005

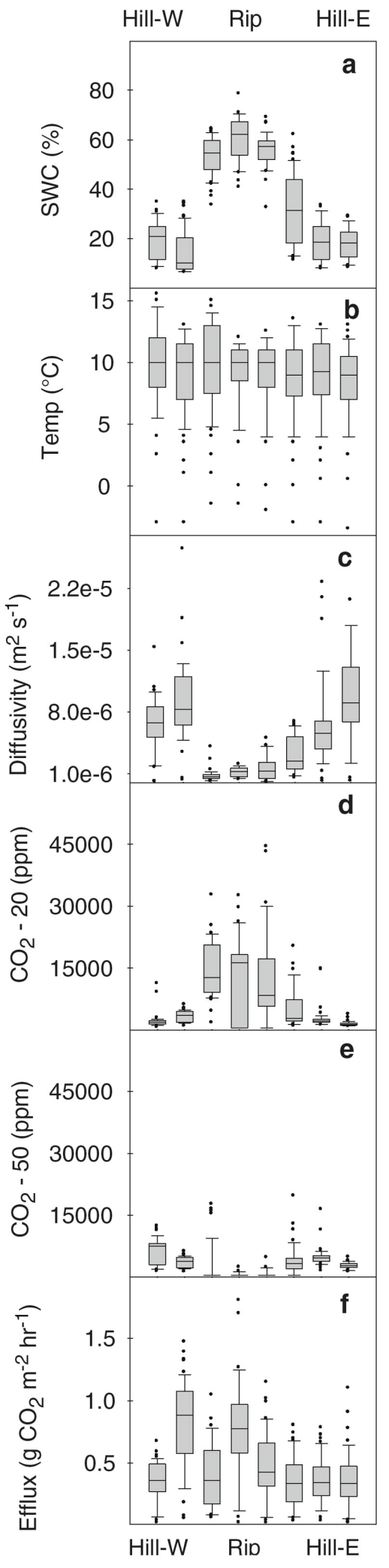


Figure 4. Two-week average a) surface $\mathrm{CO}_{2}$ efflux; b) soil gas diffusivity; c) SWC; d) soil temperature; e) soil $\mathrm{CO}_{2}$ concentrations $(20 \mathrm{~cm})$; and $\mathbf{f})$ soil $\mathrm{CO}_{2}$ concentrations $(50 \mathrm{~cm})$ from riparian (grey) and hillslope (black) landscape positions during the growing season. Whiskers represent one standard deviation (based upon 3 and 5 replications in the riparian and hillslope zones, respectively). Soil $\mathrm{CO}_{2}$ concentrations were not measured during the end of July due to equipment malfunction (therefore not allowing for calculations of soil gas diffusivity during that time).

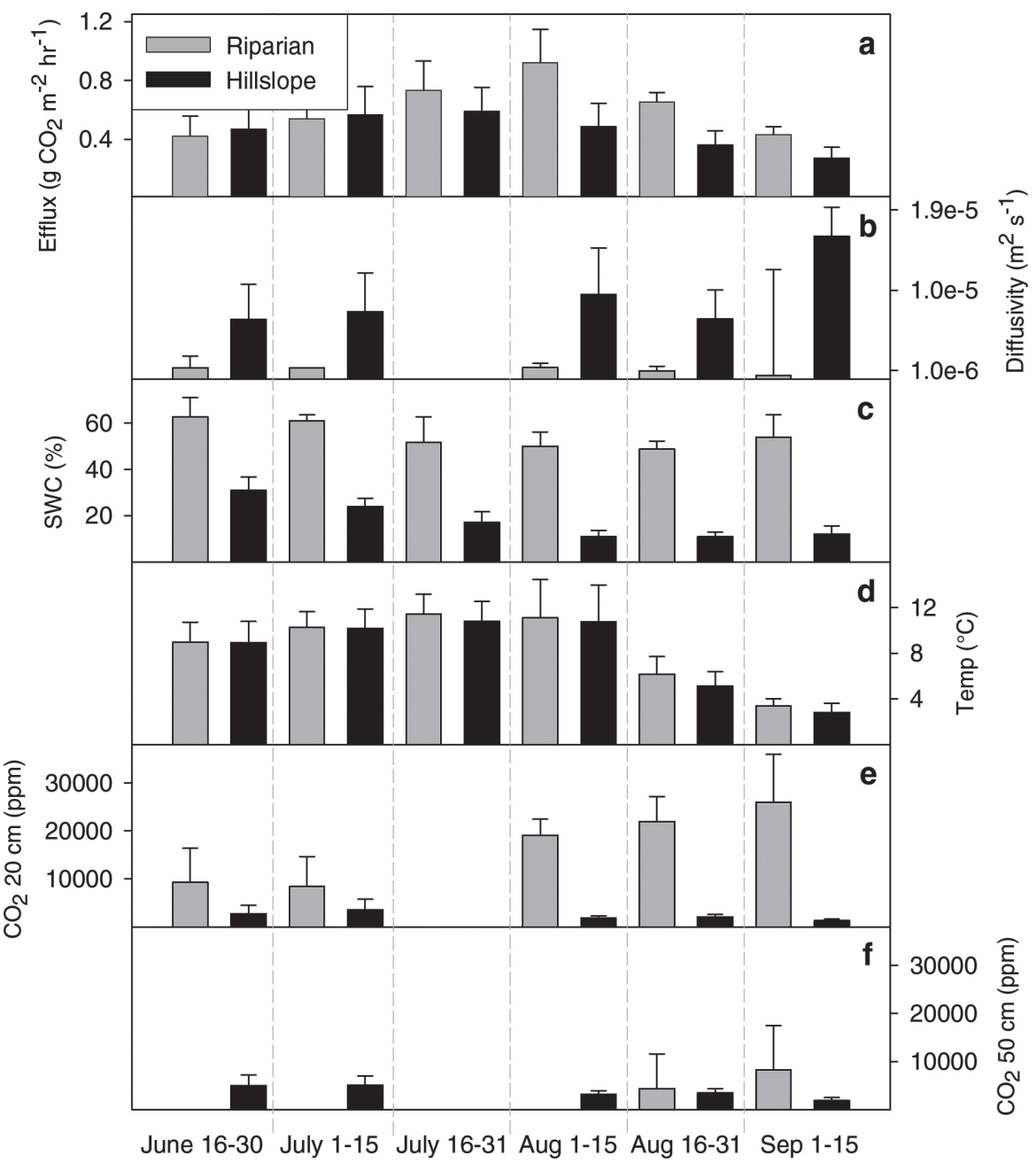

(Figure 5), which were the highest riparian concentrations measured during this study. Conversely, the hillslope zones exhibited summer peaks in soil $\mathrm{CO}_{2}$ concentrations during the beginning of July, with average values of $\sim 5,000 \mathrm{ppm}$ (Figure 6).

Surface $\mathrm{CO}_{2}$ efflux

\section{Spatial variability}

Soil surface $\mathrm{CO}_{2}$ efflux was not significantly different between riparian and hillslope zones (Table 1; Figures 3 \& 4). However, when making weekly comparisons between each riparian and hillslope nest (rather than monthly comparisons of aggregated riparian and hillslope efflux, Table 1), large differences in riparian and hillslope efflux is evident (Figure 9).

\section{Seasonal variability}

Soil surface $\mathrm{CO}_{2}$ efflux showed a high degree of seasonal variability in both riparian and hillslope zones (Figures 5, 6, \& 8). During late spring, there was snow accumulation of up to $120 \mathrm{~cm}$ (Figures 5 \& 6), and surface $\mathrm{CO}_{2}$ efflux was relatively low, $\ll 0.1 \mathrm{~g} \mathrm{CO}_{2} \mathrm{~m}^{-2} \mathrm{~h}^{-1}$ in both riparian and hillslope zones. By the middle of June, 2005, the majority of the ground surface was snow-free, and both riparian and hillslope surface $\mathrm{CO}_{2}$ efflux rose nearly an order of magnitude (Figures 5 \& 6). Average hillslope zone surface $\mathrm{CO}_{2}$ efflux peaked at $\sim 0.5 \mathrm{~g} \mathrm{CO}_{2} \mathrm{~m}^{-2} \mathrm{~h}^{-1}$ at most nests between the middle and end of July (Figure 9). Conversely, riparian zone efflux peaked at $\sim 0.8 \mathrm{~g} \mathrm{CO}_{2} \mathrm{~m}^{-2} \mathrm{~h}^{-1}$ (although up to $1.3 \mathrm{~g} \mathrm{CO}_{2} \mathrm{~m}^{-2} \mathrm{hr}^{-1}$ at T1-2) 2-4 weeks later, between the beginning and middle of August 
Figure 5. Riparian data of a) rain; b) snow depth (grey) and snow water equivalent (SWE-black); c) soil temperature; $\mathbf{d})$ soil gas diffusivity; e) soil water content; $\mathbf{f}$ ) soil surface $\mathrm{CO}_{2}$ efflux; and g) 20 and $50 \mathrm{~cm}$ soil $\mathrm{CO}_{2}$ concentrations from February 6 to October 1, 2005. Plots $\mathbf{c}-\mathbf{e}$ show the average and standard deviation of all riparian nests (based upon 3 and 5 replications in the riparian and hillslope zones, respectively). Soil temperature and SWC were not measured during the winter, and efflux measurements did not begin until the end of April. Yaxis for surface $\mathrm{CO}_{2}$ efflux is presented in both $\mathrm{g} \mathrm{CO}_{2} \mathrm{~m}^{-2} \mathrm{~h}^{-1}$ and $\mu \mathrm{mol} \mathrm{CO} \mathrm{Cm}^{-2} \mathrm{~s}^{-1}$ to aid in comparison to other studies.

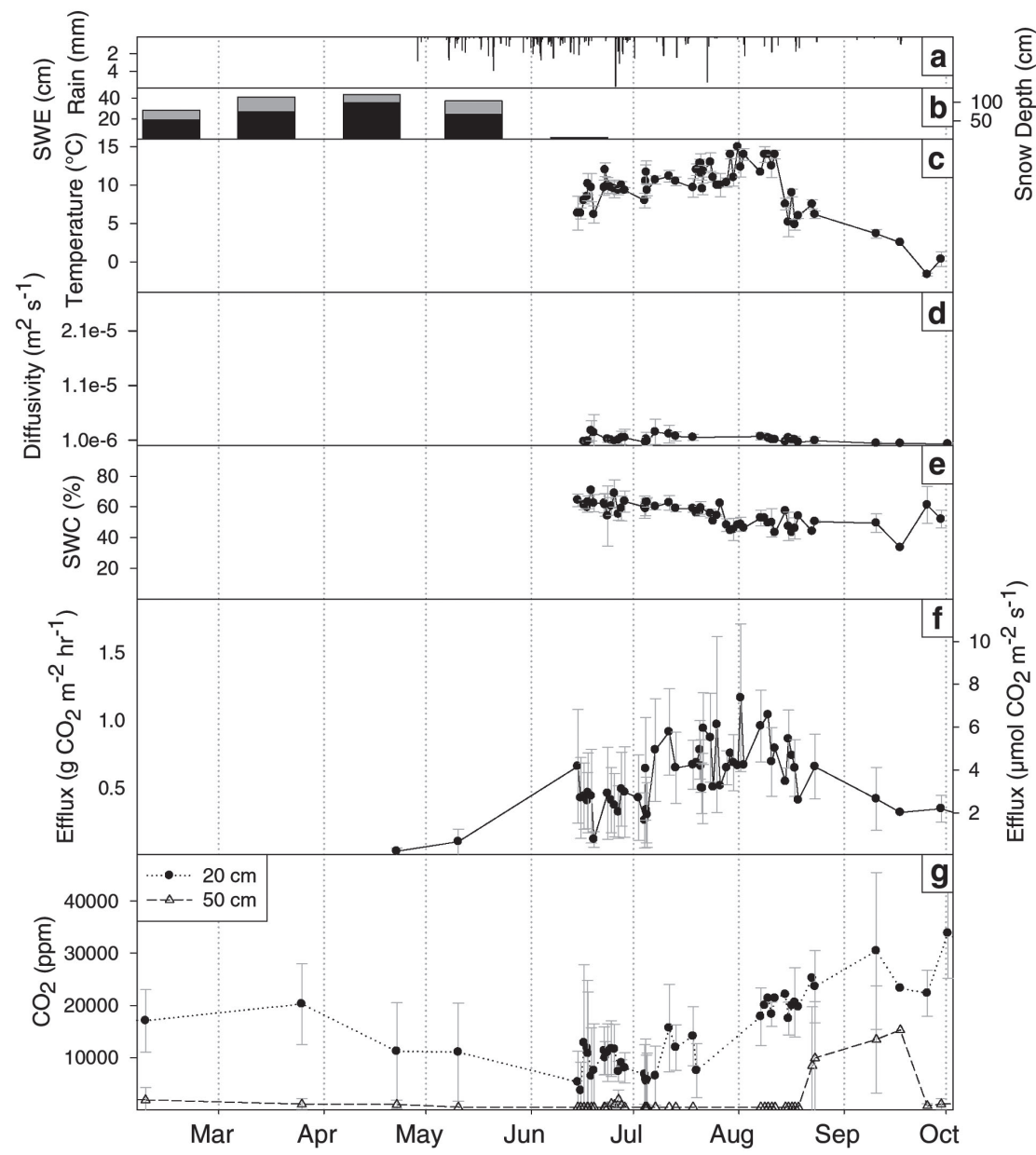

centrations at $20 \mathrm{~cm}$ were significantly higher in the riparian zones (Figures $3 \& 4$ ). This was likely the result of significantly higher and often intermediate riparian zone SWC (defined as $40-60 \%$ at the TCEF) (Figures 3 \& 4). Increasing SWC generally promotes higher soil $\mathrm{CO}_{2}$ concentrations (Davidson et al. 2000; Riveros-Iregui et al. 2007) in response to increased production and decreased transport. Our results are consistent with other investigations (Clark and Gilmour 1983; Davidson et al. 2000; Sjogersten et al. 2006), which concluded that optimal soil respiration occurred at intermediate SWC. In contrast to SWC, soil temperature showed little variability between riparian and hillslope landscape positions (Figure 3). We infer this was due to differences in canopy cover and SWC. In the riparian zones, despite an open canopy, high SWC (i.e. the high specific heat of water) likely limited the effect of relatively high incoming solar radiation on soil temperature. In contrast, low hillslope 
Figure 6. Hillslope data of a) rain; b) snow depth (grey) and snow water equivalent (SWE-black); c) soil temperature; d) soil gas diffusivity; e) soil water content; $\mathbf{f}$ ) soil surface $\mathrm{CO}_{2}$ efflux; and g) 20 and $50 \mathrm{~cm}$ soil $\mathrm{CO}_{2}$ concentrations from February 6 to October 1, 2005. Plots c-e show the average and standard deviation of all hillslope nests (based upon 3 and 5 replications in the riparian and hillslope zones, respectively). Soil temperature and SWC were not measured during the winter, and efflux measurements did not begin until the end of April. Y-axis for surface $\mathrm{CO}_{2}$ efflux is presented in both $\mathrm{g} \mathrm{CO}_{2} \mathrm{~m}^{-2} \mathrm{~h}^{-1}$ and $\mu \mathrm{mol} \mathrm{CO} \mathrm{Cm}^{-2} \mathrm{~s}^{-1}$ to aid in comparison to other studies.

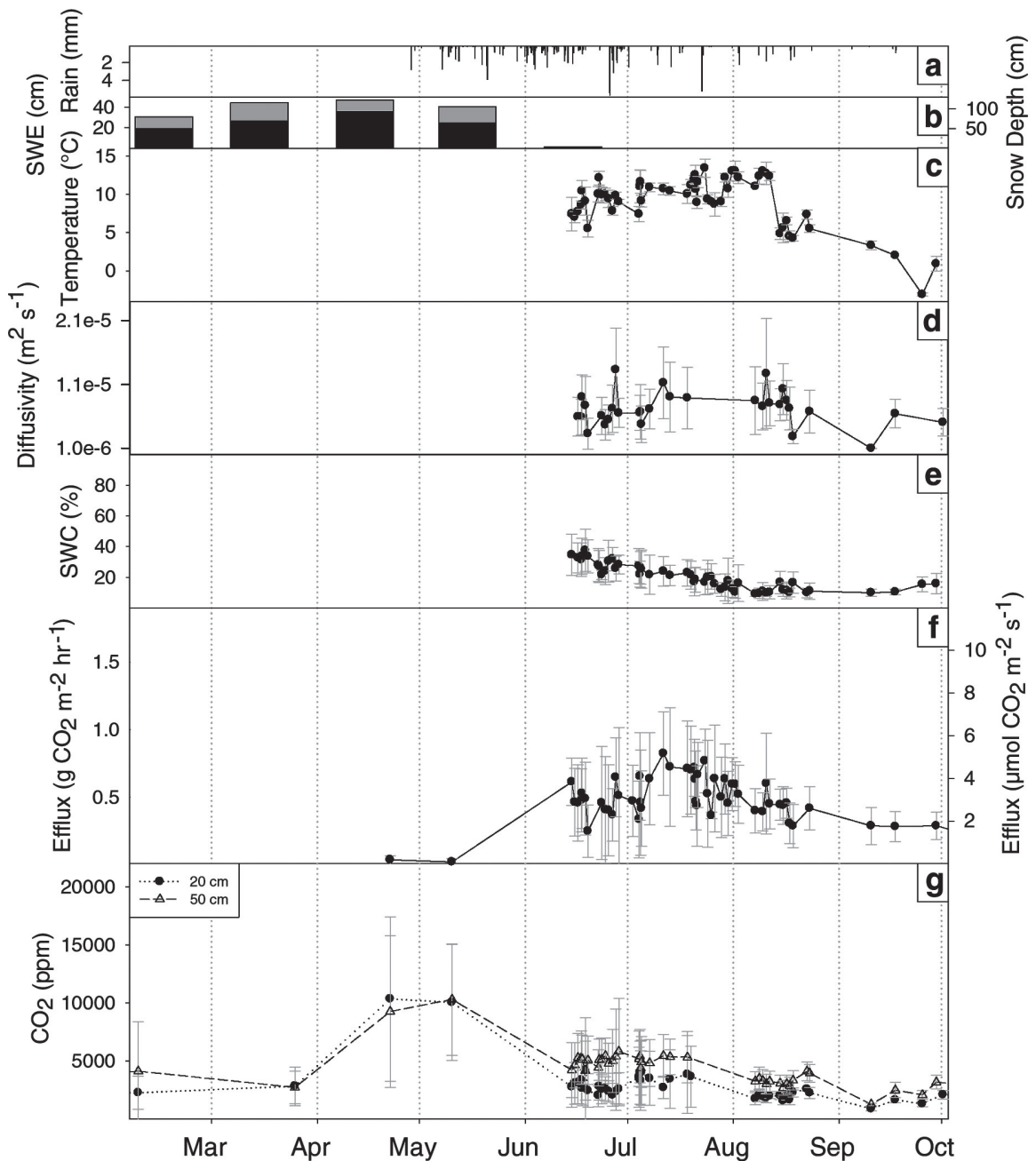

SWC, which can allow the soil to warm faster than areas with high SWC, was offset by dense canopy cover that limited incoming solar radiation in the hillslopes. These differences led to little variability in soil temperature between riparian and hillslope zones. This suggests that soil temperature had little control on the spatial variability of soil $\mathrm{CO}_{2}$ concentrations, which is consistent with the results of Scott-Denton et al. (2003) in a subalpine forest in Colorado.

\section{Within landscape positions}

Soil $\mathrm{CO}_{2}$ concentrations were more variable in the riparian zones, ranging from "flooded" to $45,000 \mathrm{ppm}$. In contrast, hillslope soil $\mathrm{CO}_{2}$ concentrations ranged from only 1,000-10,000 ppm (Figure 2). These differences were likely in response to greater variability in riparian SWC (Figures 2 \& $3)$. SWC in the riparian zones ranged from $\sim 10$ to $80 \%$, while the range of hillslope SWC was generally $5-35 \%$. The exception in the hillslopes was T23 , which had SWC of up to $\sim 60 \%$ just after snowmelt (likely due to its lower elevation and closer proximity to Stinger Creek than other hillslope locations), but low SWC during summer and fall. We partially attribute differences in riparian and hillslope SWC to groundwater table fluctuations. Within the riparian zones, groundwater table elevations ranged from near the ground surface to below groundwater well completion depths (1-2 m). Our results suggest that respiration was inhibited at many riparian gas wells at or near times of saturation, as exemplified in Figure 7 (which presents data from T1-4). Respiration at $20 \mathrm{~cm}$ was impacted by groundwater table fluctuations between 


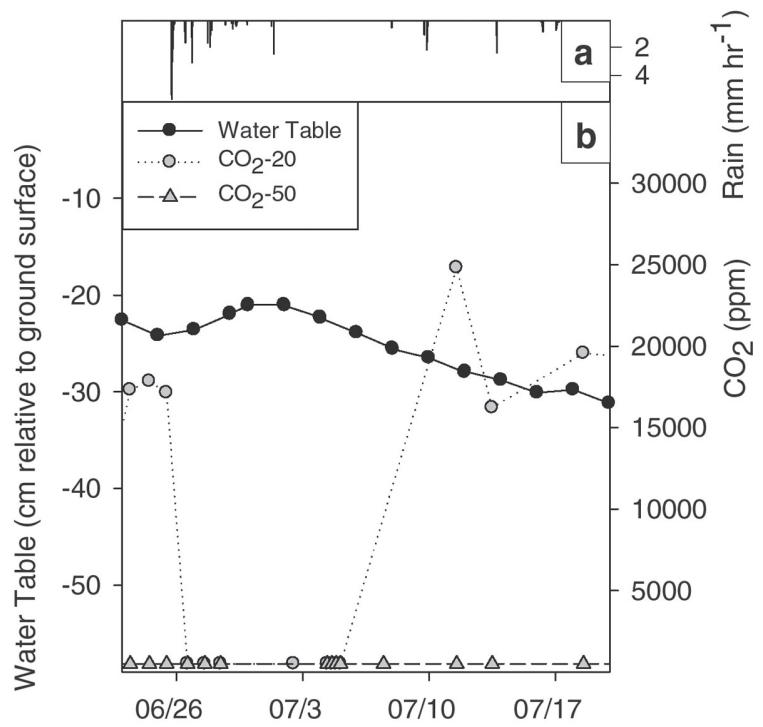

Figure 7. a) Precipitation; and b) water table depth and soil $\mathrm{CO}_{2}$ concentrations at the T1-4 nest from June 26 to July 20, 2005.

the end of June and middle of July in response to a series of precipitation events. As the groundwater table rose to $20 \mathrm{~cm}$, respiration became inhibited. However, as the groundwater table declined below $20 \mathrm{~cm}$, soil $\mathrm{CO}_{2}$ concentrations quickly increased by over $25,000 \mathrm{ppm}$. In contrast to the riparian zones, the groundwater table in the hillslopes never rose to within $50 \mathrm{~cm}$ of the ground surface during the period of measurement, partially explaining the smaller variability in hillslope SWC and therefore soil $\mathrm{CO}_{2}$ concentrations.

\section{Soil $\mathrm{CO}_{2}$ concentration by depth}

There were differences in 20 and $50 \mathrm{~cm}$ soil $\mathrm{CO}_{2}$ concentrations, with the largest differences in the riparian zones. Riparian zone soil $\mathrm{CO}_{2}$ concentrations were significantly higher at $20 \mathrm{~cm}$ (Table 1; Figure 5). This was likely in response to differences in SWC by depth (unpublished data). The magnitude of the difference between 20 and $50 \mathrm{~cm}$ soil $\mathrm{CO}_{2}$ concentrations in the riparian zones increased from early summer to fall (Figure 5), in conjunction with a decline in groundwater table depth. After snowmelt, many riparian locations at both 20 and $50 \mathrm{~cm}$ were saturated, which inhibits soil $\mathrm{CO}_{2}$ production. $50 \mathrm{~cm}$ gas wells remained saturated at many riparian zone nests, while soil $\mathrm{CO}_{2}$ concen- trations at $20 \mathrm{~cm}$ quickly increased as the summer progressed and the groundwater table declined below $20 \mathrm{~cm}$ (Figure 7). This led to a spring-fall increase in the difference in soil $\mathrm{CO}_{2}$ concentrations by depth in the riparian zones.

In contrast to the riparian zones, hillslope soil $\mathrm{CO}_{2}$ concentrations were relatively homogenous between the 20 and $50 \mathrm{~cm}$ depth, with slightly higher concentrations at $50 \mathrm{~cm}$ (Figure 6). The groundwater table in the hillslopes never rose to within $50 \mathrm{~cm}$ of the ground surface. This resulted in similar SWC at 20 and $50 \mathrm{~cm}$ (relative to the riparian zones), and led to comparable soil $\mathrm{CO}_{2}$ concentrations by depth. Our results suggest that groundwater table fluctuations and saturated conditions had little to no effect on the small differences in soil $\mathrm{CO}_{2}$ concentrations observed in the hillslopes. Also in contrast to the riparian zones, the magnitude of the difference in hillslope soil $\mathrm{CO}_{2}$ concentrations decreased from early summer to fall (Figure 6). Following peak snowmelt, SWC at $20 \mathrm{~cm}$ was higher than at $50 \mathrm{~cm}$ in response to greater melt-water infiltration into the upper soil horizons. However, as the summer progressed, SWC at $20 \mathrm{~cm}$ decreased more rapidly than at $50 \mathrm{~cm}$, likely in response to high surface evaporation and soil drainage, which led to similar SWC at 20 and $50 \mathrm{~cm}$. We suggest that the decrease in the magnitude of the difference in SWC by depth in the hillslopes led to the springfall decrease in the difference of $\mathrm{CO}_{2}$ concentrations by depth.

How does the timing of peak soil $\mathrm{CO}_{2}$ concentrations differ between riparian and hillslope zones?

\section{Winter soil $\mathrm{CO}_{2}$ concentrations}

We observed distinct differences in the timing of winter soil $\mathrm{CO}_{2}$ concentration peaks between the riparian and hillslope zones. Riparian soil $\mathrm{CO}_{2}$ concentrations peaked at $\sim 20,000 \mathrm{ppm}$ between midMarch and mid-April, 2005, while hillslope nests peaked at $\sim 10,000$ ppm 4-8 weeks later, between mid-April and mid-May (Figures 5 \& 6). This corresponded to the time of the deepest snowpack and greatest snow water equivalent of the year (120 and $46 \mathrm{~cm}$, respectively, Figures 5 \& 6). A deep snowpack can lead to increased soil $\mathrm{CO}_{2}$ concentrations due to its insulating effects (Sommerfeld et al. 1996; Schadt et al. 2003) (allowing for relatively 


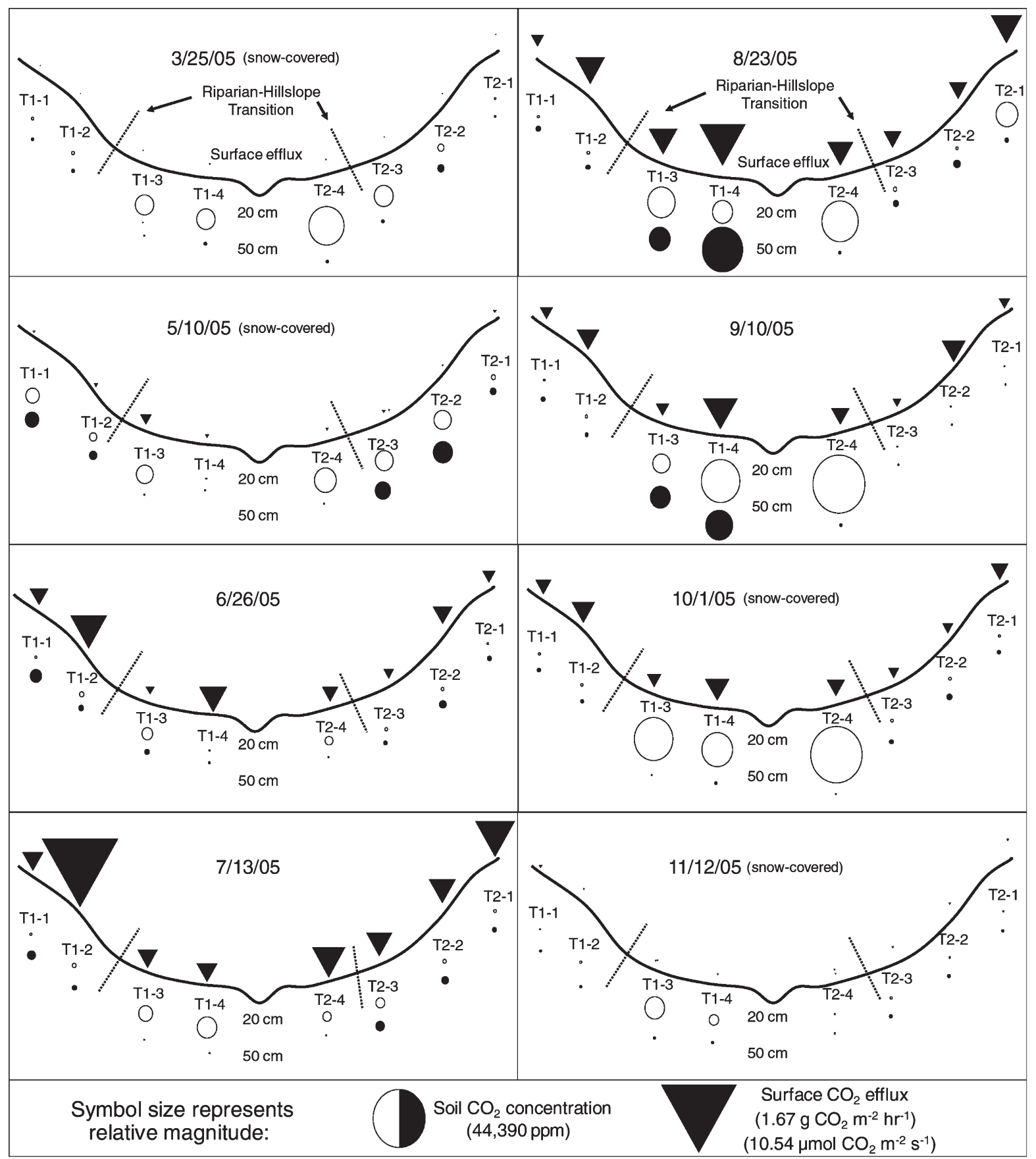

Figure 8. Cross-section schematics of soil $\mathrm{CO}_{2}$ concentrations at $20 \mathrm{~cm}$ (white circles) and $50 \mathrm{~cm}$ (black circles), and surface $\mathrm{CO}_{2}$ efflux (triangles) at all nest locations at eight points in time. Note: symbol size represents relative magnitude.

high production compared to colder soils) and low gas diffusivity (Hamada and Tanaka 2001; Norton et al. 2001). Differences in the timing of peak winter $\mathrm{CO}_{2}$ concentrations (4-8 weeks later in the hillslopes) were likely the result of differences in the snow energy balance. The snow in the riparian zones became isothermal and ripe sooner than in the hillslopes due to an open canopy (riparian zones melting first were observed in our study watershed). This resulted in earlier melt infiltration, 


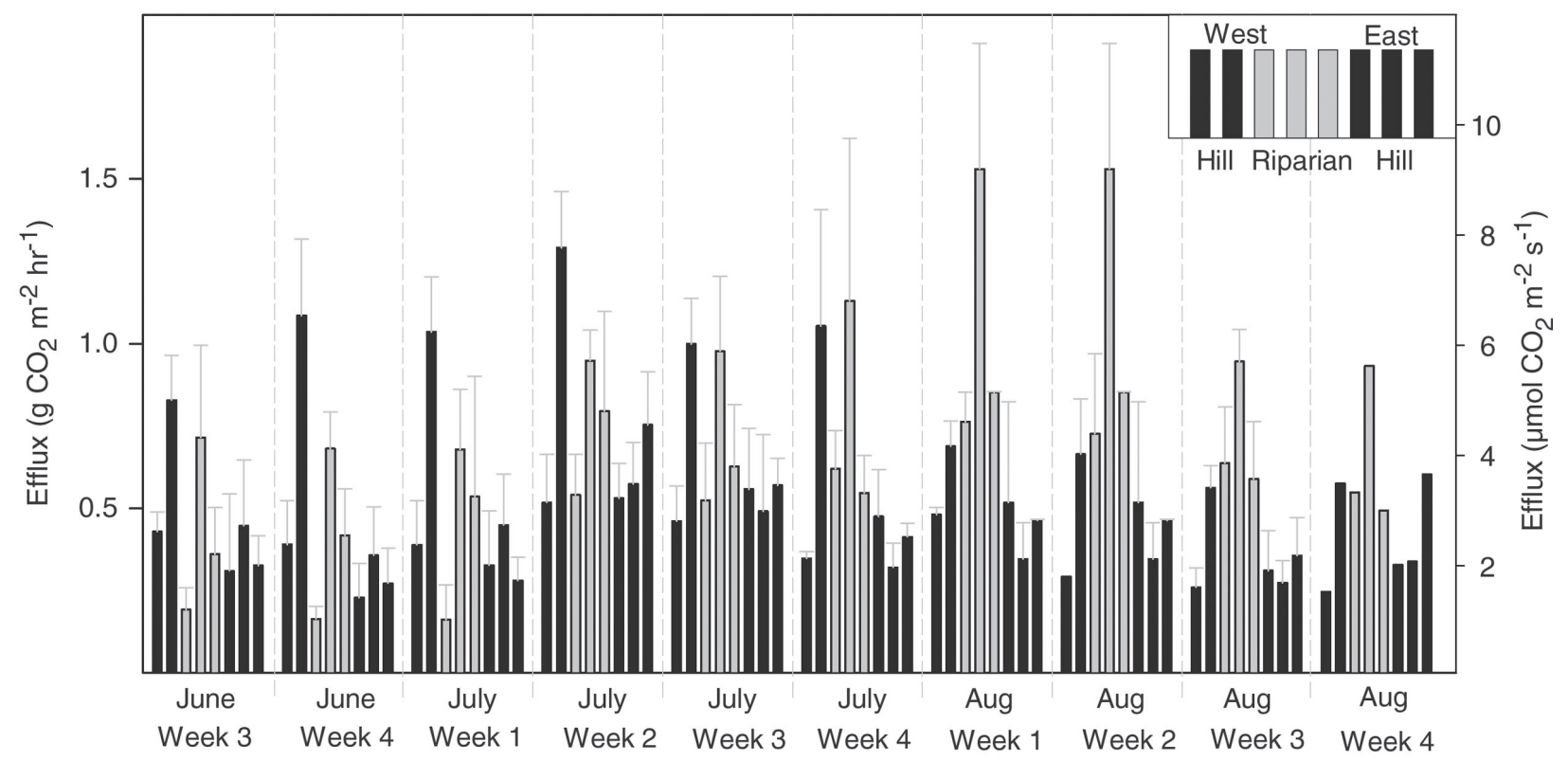

Figure 9. Weekly surface $\mathrm{CO}_{2}$ efflux from riparian (grey) and hillslope (black) nests from June 14 to August 31, 2005. Whiskers represent one standard deviation (based upon 3 and 5 replications in the riparian and hillslope zones, respectively).

which likely stimulated respiration (Brooks et al. 2005; Hirano 2005) and/or increased the diffusive resistance of the snow (Musselman et al. 2005; Monson et al. 2006). Musselman et al. (2005) observed a similar trend, with soil $\mathrm{CO}_{2}$ concentrations under a deep snowpack increasing sooner in a meadow than in a forest at a subalpine site in Wyoming.

Peaks in winter soil $\mathrm{CO}_{2}$ concentrations in our study watershed ( 20,000 and 10,000 ppm in the riparian and hillslope zones, respectively; Figures 5 \& 6) were substantially higher than those measured at other subalpine locations. Musselman et al. (2005) reported a range of 1,000-5,000 ppm at an elevation of 3,100 $\mathrm{m}$ in Wyoming; Monson et al. (2006) observed a range from $\sim 500$ to $2,700 \mathrm{ppm}$ at an elevation of 3,030 $\mathrm{m}$ at Niwot Ridge in Colorado; and Sommerfeld et al. (1996) measured a winter peak of $10,464 \mathrm{ppm}$ at a subalpine meadow at $3,180 \mathrm{~m}$ in Wyoming. One possible explanation for higher winter soil $\mathrm{CO}_{2}$ concentrations at TCEF is its lower elevation $(\sim 2,200 \mathrm{~m})$ than those studies cited above. At this elevation in the northern Rocky Mountains, a deep snowpack ( 1-2 m) is often present for over 6 months of the year (generally from mid-October to mid-May). Despite similar winter soil temperatures between the TCEF and the above-cited studies, air temperatures were generally higher in the TCEF due to its lower elevation.
This increases the likelihood of above-freezing air temperatures to occur intermittently over the winter (which was observed at TCEF). We suggest this increased the frequency of melt-refreeze events, which can impact snowpack structure and metamorphism, gas diffusion, and soil $\mathrm{CO}_{2}$ concentrations (Musselman et al. 2005, Monson et al. 2006).

\section{Growing season soil $\mathrm{CO}_{2}$ concentrations}

The timing of peak growing season soil $\mathrm{CO}_{2}$ concentrations depended upon landscape position and was likely the result of differences in soil gas diffusivity, groundwater table fluctuations, and respirationinhibiting SWC. Peaks in hillslope soil $\mathrm{CO}_{2}$ concentrations occurred during the middle to end of June, when SWC was high and soil temperature began to rise, which generally increases soil $\mathrm{CO}_{2}$ production (Hamada and Tanaka 2001; Raich et al. 2002; Pendall et al. 2004). However, hillslope SWC generally remained below $40 \%$ (Figures 3, 4), leading to high soil gas diffusivity (Figure 4). In contrast, peaks in riparian zone soil $\mathrm{CO}_{2}$ concentrations did not occur until September (Figure 5), due to high, respirationinhibiting SWC. As the groundwater table declined below the depth of many riparian gas wells, resulting in intermediate SWC, it is likely that increases in soil $\mathrm{CO}_{2}$ production led to sharp rises in soil $\mathrm{CO}_{2}$ 
concentrations. This resulted in the highest riparian zone soil $\mathrm{CO}_{2}$ concentrations of the year. In contrast, maximum hillslope concentrations occurred during snowmelt, which was generally the only time that hillslope SWC approached an intermediate range throughout the study period. Thus, the relative magnitude of riparian and hillslope soil $\mathrm{CO}_{2}$ concentrations reversed from spring to fall, with higher hillslope values in the spring and larger riparian values during the fall.

How does the timing and magnitude of peak surface $\mathrm{CO}_{2}$ efflux differ between riparian and hillslope zones?

Similar to soil $\mathrm{CO}_{2}$ concentrations, the timing of maximum surface $\mathrm{CO}_{2}$ efflux varied between riparian and hillslope zones, but was more coincident across the transect than the timing of maximum $\mathrm{CO}_{2}$ concentrations (Figure 8). Maximum hillslope efflux $\left(0.82 \mathrm{~g} \mathrm{CO}_{2} \mathrm{~m}^{-2} \mathrm{~h}^{-1}\right)$ occurred between the middle and end of July (Figure 6), while maximum riparian efflux $\left(1.16 \mathrm{~g} \mathrm{CO}_{2} \mathrm{~m}^{-2} \mathrm{~h}^{-1}\right)$ occurred 2-4 weeks later, between the beginning and middle of August (Figure 5). We suggest that differential timing of riparian and hillslope peak surface $\mathrm{CO}_{2}$ efflux is partially due to timing of optimal combinations of soil $\mathrm{CO}_{2}$ production and transport. During the middle and end of July, SWC was the highest measured over the growing season (Figure 6). This likely led to high hillslope soil $\mathrm{CO}_{2}$ production (relative to the riparian zones), and resulted in maximum hillslope surface $\mathrm{CO}_{2}$ efflux between the middle and end of July (Figures 4 \& 5). In contrast, riparian zone SWC did not decrease to intermediate values (defined as $40-60 \%$ in the TCEF) that are optimal for soil $\mathrm{CO}_{2}$ production (Clark and Gilmour 1983; Davidson et al. 2000; Sjogersten et al. 2006) until the beginning of August (Figure 5). This decrease in SWC also led to increased soil gas transport and resulted in maximum surface $\mathrm{CO}_{2}$ efflux between the beginning and middle of August. Our data indicates that maximum surface $\mathrm{CO}_{2}$ efflux occurs at optimal combinations of production and transport, the timing of which can vary across riparian and hillslope zones.

In general, differences in riparian and hillslope surface $\mathrm{CO}_{2}$ efflux were not statistically significant when data was analyzed by month (Table 1). However, when comparing data over shorter timescales, (e.g. biweekly [Figure 4] or weekly [Figure 9]), differences in riparian and hillslope soil surface $\mathrm{CO}_{2}$ efflux become more apparent. Surface $\mathrm{CO}_{2}$ efflux is controlled by both soil $\mathrm{CO}_{2}$ production and transport, and it is likely that changes in the drivers of soil respiration become balanced over monthly timescales. For example, a decrease in SWC can simultaneously increase soil gas diffusivity and decrease soil $\mathrm{CO}_{2}$ production. SWC often decreases more slowly in riparian zones due to riparian zone groundwater storage and upland drainage (lateral redistribution of water), resulting in more sustained groundwater tables (Beven and Kirkby 1979; Pennock et al. 1987; McGlynn and Seibert 2003). It is thus likely that responses in soil $\mathrm{CO}_{2}$ production and transport to changes in SWC differ between riparian and hillslope zones. This can lead to variability in riparian and hillslope soil surface $\mathrm{CO}_{2}$ efflux over short timescales (weekly or biweekly), while such differences likely become balanced over intermediate (defined as monthly in this study) timescales. Our results also demonstrate that differences in riparian and hillslope efflux may exist over longer timescales (e.g. across seasons). Cumulative growing season efflux was $57 \%$ higher in the riparian zones than the hillslopes $(p=0.01)$ and averaged 1346 and $858 \mathrm{~g} \mathrm{CO}_{2} \mathrm{~m}^{-2}$, respectively. We suggest that studies of soil respiration need to collect measurements of soil $\mathrm{CO}_{2}$ concentrations, soil gas diffusivity, and surface $\mathrm{CO}_{2}$ efflux over both short (e.g. weekly or biweekly rather than monthly) and long (seasonal) timescales as well as at multiple locations in order to accurately quantify differences in surface $\mathrm{CO}_{2}$ efflux across the landscape.

Do higher soil $\mathrm{CO}_{2}$ concentrations necessarily result in higher efflux (i.e. does surface $\mathrm{CO}_{2}$ efflux follow patterns of subsurface $\mathrm{CO}_{2}$ )?

The efflux of $\mathrm{CO}_{2}$ from the soil to the atmosphere is strongly controlled by $\mathrm{CO}_{2}$ concentration gradients (Equation 2), as efflux increases with increasing concentration gradients (holding other variables in Equation 2 constant). Soil $\mathrm{CO}_{2}$ concentrations were significantly higher in the riparian zones (Figures 3 $\& 4$; Table 1). This resulted in concentration gradients from the soil to the atmosphere that were often over an order of magnitude higher than in the hillslopes (e.g. 30,000-400 ppm in the riparian zones versus 3,000-400 ppm in the hillslopes), and sug- 
gested that riparian zone soil surface $\mathrm{CO}_{2}$ efflux would be high. However, high riparian zone SWC limited riparian zone soil gas transport (Washington et al. 1994; Davidson and Trumbore 1995; Moldrup et al. 2004) and led to less than expected surface $\mathrm{CO}_{2}$ efflux. In contrast, small hillslope $\mathrm{CO}_{2}$ concentration gradients suggested that soil surface $\mathrm{CO}_{2}$ efflux would be low in the hillslopes. However, low SWC led to hillslope zone soil gas diffusivity rates that were often over an order of magnitude higher than in the riparian zones (Figure 4), which resulted in higher than expected hillslope soil surface $\mathrm{CO}_{2}$ efflux. This variability in transport in response to significant differences in riparian and hillslope SWC $(p \ll 0.01)$ led to insignificant differences in monthly-timescale ANOVA analysis (Figures 2 \& 4). Despite this, cumulative efflux was $57 \%$ higher in the riparian zones over the growing season and suggests $57 \%$ greater production in the riparian zones as compared to the adjacent hillslopes.

\section{Conceptual model}

Our study suggests that soil surface $\mathrm{CO}_{2}$ efflux across two riparian-hillslope transitions was controlled by a shift between production- and transport-limiting SWC over seasonal timescales (Figure 10). Soil $\mathrm{CO}_{2}$ concentrations often changed concurrent with changes in SWC, with the highest concentrations generally at intermediate SWC. Previous research (Clark and Gilmour 1983; Davidson et al. 2000; Sjogersten et al. 2006) indicates intermediate SWC optimality for soil $\mathrm{CO}_{2}$ production as sharp decreases in production can occur at very high or low SWC. However, transport generally decreases with increasing SWC. In our study, surface $\mathrm{CO}_{2}$ efflux was relatively similar between riparian and hillslope zones over short timescales (weekly or monthly) (Figure 4, Table 1), likely the result of different balances between soil $\mathrm{CO}_{2}$ production and transport (Figure 10). Our results indicate that riparian zones had high production and low transport in response to high SWC, while the opposite was true in the hillslopes. This combination of SWC-mediated production and transport led to equifinality in efflux between riparian and hillslope zones at short timescales. However, cumulative growing season efflux was $57 \%$ higher in the riparian zones $(p=0.01)$, which suggests higher riparian zone soil $\mathrm{CO}_{2}$ production. Our conceptual model diagram (Figure 10) indicates that hillslopes have optimal conditions for efflux in late spring and early summer (following snowmelt, when SWC is near the intermediate zone and soil temperatures begin to increase). In contrast, riparian zones move toward optimal conditions in mid to late summer (after snowmelt drydown, as SWC approaches an intermediate range and soil temperatures are high), partially explaining differences in the timing and magnitude of soil $\mathrm{CO}_{2}$ concentrations and surface $\mathrm{CO}_{2}$ efflux.

Implications at the landscape scale

The results of our study illustrate that differences in the spatial and temporal variability of soil respiration may exist in response to topographic gradients and landscape position. High elevation mountain ecosystems play an important role in the global C cycle (Schimel et al. 2002). Therefore, understanding the variability of soil respiration in complex terrain is important, especially for understanding the

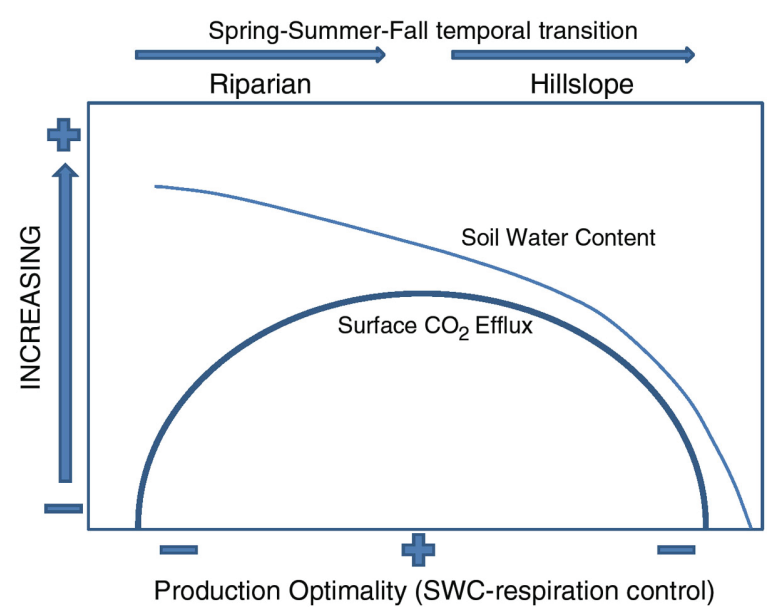

Figure 10. Conceptual model of soil $\mathrm{CO}_{2}$ production and optimality of SWC. Surface $\mathrm{CO}_{2}$ efflux over seasonal timescales is a function of both soil gas production and diffusion. Maximum optimality of surface $\mathrm{CO}_{2}$ efflux generally occurs at intermediate levels of SWC, which is optimal for soil $\mathrm{CO}_{2}$ production. Transport generally increases with decreases in SWC. Hillslopes began their spring-tosummer seasonal shift at an intermediate SWC, which led to early season efflux maxima. In contrast, riparian zones began their seasonal shift at high SWC (often saturation), and maxima efflux did not occur until late summer or early fall when SWC approached intermediate values. 
dynamic thresholds and drivers of ecosystem C exchange, attempting to scale point observations to whole watersheds, and simulating and modeling soil respiration. Understanding of the relative controls of environmental variables on the heterogeneity of soil respiration through space and time is also critical for predicting changes in soil $\mathrm{CO}_{2}$ dynamics in response to climate change (e.g. wet versus dry years, increased/decreased air and soil temperatures, changes in snow depth and timing of peak snowmelt), and ecosystem disturbance.

\section{Conclusions}

Based on measurement and analysis of soil $\mathrm{CO}_{2}$ concentrations (20 and $50 \mathrm{~cm}$ ), surface $\mathrm{CO}_{2}$ efflux, soil temperature, SWC, and calculations of soil gas diffusivity across two riparian-hillslope transitions within the upper-Stringer Creek Watershed, we conclude that:

1. Hillslope zone soil $\mathrm{CO}_{2}$ concentrations peaked during the late spring when snow depth and snow water equivalent were greatest. Conversely, riparian zone soil $\mathrm{CO}_{2}$ concentrations peaked during the early fall when SWC declined to intermediate (optimal) levels.

2. Surface $\mathrm{CO}_{2}$ efflux increased over an order of magnitude from spring to summer in both riparian and hillslope zones. Hillslope surface $\mathrm{CO}_{2}$ efflux peaked between the middle and end of July, while riparian efflux peaked 2-4 weeks later. This differential timing of riparian and hillslope peak surface $\mathrm{CO}_{2}$ efflux was likely in response to the earlier and more rapid decrease of SWC in the hillslopes.

3. Soil surface $\mathrm{CO}_{2}$ efflux was relatively homogenous at short timescales across both riparian and hillslope zones as compared to riparian zone soil $\mathrm{CO}_{2}$ concentrations that were greater and more variable than the adjacent hillslopes. Similar efflux over short timescales was likely the result of equifinality due to differential mechanistic controls on $\mathrm{CO}_{2}$ production and transport. However, cumulative integration of growing season efflux shows $57 \%$ higher riparian zone efflux, which suggests that soil $\mathrm{CO}_{2}$ production is higher in the riparian zones.
This research provides insight into the biophysical controls of soil respiration: soil temperature, SWC, soil gas diffusivity, snowpack, groundwater table fluctuations, and landscape position. To continue to improve our understanding of the spatial and temporal variability of soil $\mathrm{CO}_{2}$ dynamics, it is imperative that further studies across a range of spatial and temporal scales be undertaken, especially in complex terrain.

Acknowledgements - We gratefully acknowledge the Tenderfoot Creek Experimental Forest and the USDA, Forest Service, Rocky Mountain Research Station, especially Ward McCaughey for research access and logistical support, field assistance from Kelsey Jencso, Becca McNamara, Kelley Conde, and Austin Allen, assistance with statistical analysis from Dr. Lucy Marshall, and colleague reviews from Dr. Catherine Zabinski and Dr. Mark Skidmore. This work was funded by the NSF Integrated Carbon Cycle Research Program (ICCR, NSF grants EAR0404130, EAR0403924, and EAR0403906) and fellowships awarded to V.J. Pacific by the Inland Northwest Research Alliance (INRA), Montana Water Center Student Research Grant Program, and the Big Sky Institute NSF GK-12 program. We are also thankful for comments by two anonymous reviewers for Biogeochemistry and by Associate Editor Jan Mulder, the incorporation of which have significantly improved the quality of this manuscript.

\section{References}

Andrews JA, Schlesinger WH (2001) Soil $\mathrm{CO}_{2}$ dynamics, acidification, and chemical weathering in a temperate forest with experimental $\mathrm{CO}_{2}$ enrichment. Global Biogeochem Cycles 15:149-162. doi: 10.1029/2000GB001278

Baldocchi D, Tang J, Xu L (2006) How switches and lags in biophysical regulators affect spatial-temporal variation of soil respiration in an oak-grass savanna. J Geophys Res 111:G02008. doi: 10.1029/2005JG000063

Beven KJ, Kirkby MJ (1979) A physically-based variable contributing area model of basin hydrology. Hydrol Sci Bull 24:43-69

Brooks PD, McKnight D, Elder K (2005) Carbon limitations of soil respiration under winter snowpacks: potential feedbacks between growing season and winter carbon fluxes. Glob Change Biol 11:231-238. doi: 10.1111/j.1365-2486.2004.00877.x

Buchmann N, Guehl JM, Barigah TS, Ehleringer JR (1997) Interseasonal comparison of $\mathrm{CO}_{2}$ concentrations, isotopic composition, and carbon dynamics in an Amazonian rainforest (French Guiana). Oecologia 110:120-131. doi: 10.1007/s004420050140 
Buchmann N, Hinckley TM, Ehleringer JR (1998) Carbon isotope dynamics in Abies amabilis stands in the Cascades. Can J For Res 28:808-819. doi: 10.1139/ cjfr-28-6-808

Clark MD, Gilmour JT (1983) The effect of temperature on decomposition at optimum and saturated soil water contents. Soil Sci Soc Am J 47:927-929

Conant RT, Klopatek JM, Malin RC, Klopatek CC (1998) Carbon pools and fluxes along an environmental gradient in northern Arizona. Biogeochemistry 43:43-61. doi: 10.1023/A:1006004110637

Conant RT, Dalla-Betta P, Klopatek CC, Klopatek JM (2004) Controls on soil respiration in semiarid soils. Soil Biol Biogeochem 36:945-951. doi: 10.1016/j. soilbio.2004.02.013

Davidson EA, Trumbore SE (1995) Gas diffusivity and production of $\mathrm{CO}_{2}$ in deep soils of the eastern Amazon. Tellus 47B:550-565

Davidson EA, Verchot LV, Cattanio JH et al (2000) Effects of soil water content on soil respiration in forests and cattle pastures of eastern Amazonia. Biogeochemistry 48:53-69. doi: 10.1023/ A:1006204113917

Fang C, Moncrieff JB, Gholz HL, Clark KL (1998) Soil $\mathrm{CO}_{2}$ efflux and its spatial variation in a Florida slash pine plantation. Plant Soil 205:135-146. doi: 10.1023/A:1004304309827

Farnes PE, Shearer RC, McCaughey WW, Hanson KJ (1995) Comparisons of hydrology, geology and physical characteristics between Tenderfoot Creek experimental forest (East Side) Montana, and Coram experimental Forest (West Side) Montana. Final Report RJVA-INT-92734.USDA Forest Service, Intermountain Research Station, Forestry Sciences Laboratory, Bozeman

Grayson R, Western A (2001) Terrain and the distribution of soil moisture. Hydrol Process 15:2689-2690. doi: 10.1002/hyp.479

Hamada Y, Tanaka T (2001) Dynamics of carbon dioxide in soil profiles based on long-term field observation. Hydrol Process 15:1829-1845. doi: 10.1002/hyp.242

Happell JD, Chanton JP (1993) Carbon remineralization in a north Florida swamp forest: effects of water level on the pathways and rates of soil organic matter decomposition. Global Biogeochem Cycles 7:475-490. doi: 10.1029/93GB00876

Hillel D (2004) Introduction to environmental soil physics. Elsevier Academic Press, San Diego

Hirano T (2005) Seasonal and diurnal variations in topsoil and subsoil respiration under snowpack in a temperate deciduous forest. Global Biogeochem Cycles 19:GB2011. doi: 10.1029/2004GB002259

Holdorf HD (1981) Soil Resource Inventory, Lewis and Clark National Forest-Interim In-Service Report. On file with the Lewis and Clark National Forest. Forest Supervisor's Office, Great Falls

Kang S, Doh S, Dongsun Lee et al (2003) Topo- graphic and climatic controls on soil respiration in six temperate mixed-hardwood forest slopes, Korea. Glob Change Biol 9:1427-1437. doi: 10.1046/j.1365-2486.2003.00668.x

Kang S, Lee D, Kimball J (2004) The effects of spatial aggregation of complex topography on hydro-ecological process simulations within a rugged forest landscape: development and application of a satellite-based topoclimatic model. Can J For Res 34:519530. doi: 10.1139/x03-213

Kang S, Lee D, Lee J, Running S (2006) Topographic and climatic controls on soil environments and net primary production in a rugged temperate hardwood forest in Korea. Ecol Res 21:64-74. doi: 10.1007/ s11284-005-0095-0

Kelliher FM, Ross DJ, Law BE et al (2004) Limitations to carbon mineralization in litter and mineral soil of young and old ponderosa pine forests. For Ecol Manag 191:201-213. doi: 10.1016/j.foreco.2003.12.005

McCarthy KA, Johnson RL (1995) Measurement of trichloroethylene diffusion as a function of moisture content in sections of gravity-drained soil columns. J Environ Qual 24:49-55

McDowell NG, Marshall JD, Hooker TD, Musselman R (2000) Estimating $\mathrm{CO}_{2}$ fluxes from snowpacks at three sites in the Rocky Mountains. Tree Physiol 20:745-753

McGlynn BL, Seibert J (2003) Distributed assessment of contributing area and riparian buffering along stream networks. Water Resour Res 39. doi: 10.1029/2002WR001521

McGlynn BL, McDonnell JJ, Bramer DD (2002) A review of the evolving perceptual model of hillslope flowpaths at the Maimai catchments, New Zealand. J Hydrol (Amst) 257:1-26. doi: 10.1016/ S0022-1694(01)00559-5

McLain J, Martens D (2006) Moisture controls on trace gas fluxes in semiarid riparian soils. Soil Sci Soc Am J 70:367-377. doi: 10.2136/sssaj2005.0105

Millington RJ (1959) Gas diffusion in porous media. Science 130:100-102. doi: 10.1126/science.130.3367.100-a

Mincemoyer SA, Birdsall JL (2006) Vascular flora of the Tenderfoot Creek Experimental Forest, Little Belt Mountains, Montana. Madrono 53:211-222. doi: 10.3120/0024-9637(2006)53[211:VFOTTC]2.0.CO;2

Moldrup P, Olsen T, Schjønning P, Yamaguchi T, Rolston DE (2000) Predicting the gas diffusion coefficient in undisturbed soil from soil water characteristics. Soil Sci Soc Am J 64:94-100

Moldrup P, Olsen T, Komatsu T, Schjønning P, Rolston DE (2001) Tortuosity, diffusivity, and permeability in the soil liquid and gaseous phases. Soil Sci Soc Am J 65:613-623

Moldrup P, Olsen T, Yoshikawa S, Komatsu T, Rolston DE (2004) Three-porosity model for predicting the gas diffusion coefficient in undisturbed soil. Soil Sci Soc Am J 68:750-759 
Monson RK, Burns SP, Williams MW et al (2006) The contribution of beneath-snow soil respiration to total ecosystem respiration in a high-elevation, subalpine forest. Global Biogeochem Cycles 20:GB3030. doi: 10.1029/2005GB002684

Musselman RC, Massman WJ, Frank JM, Korfmacher JL (2005) The temporal dynamics of carbon dioxide under snow in a high elevation Rocky Mountain subalpine forest and meadow. Arct Antarct Alp Res 37:527-538. doi: 10.1657/1523-0430(2005)037[0527:TT DOCD]2.0.CO;2

Norton SA, Cosby BJ, Hernandez IJ et al (2001) Longterm and seasonal variations in $\mathrm{CO}_{2}$ : Linkages to catchment alkalinity generation. Hydrol Earth Sci Syst 5:83-91

Oades JM (1988) The retention of organic-matter in soils. Biogeochemistry 5:35-70. doi: 10.1007/BF02180317

Orchard VA, Cook FJ (1983) Relationship between soil respiration and soil-moisture. Soil Biol Biochem 15:447-453. doi: 10.1016/0038-0717(83)90010-X

Pendall E, Bridgham S, Hanson P et al (2004) Belowground process response to elevated $\mathrm{CO}_{2}$ and temperature: a discussion of observations, measurement methods, and models. New Phytol 162:311-322. doi: 10.1111/j.1469-8137.2004.01053.x

Pennock DJ, Zebarth BJ, De Jong E (1987) Landform classification and soil distribution in hummocky terrain, Saskatchewan, Canada. Geoderma 40:297-315. doi: 10.1016/0016-7061(87)90040-1

Raich JW, Potter CS (1995) Global patterns of carbon dioxide emissions from soils. Global Biogeochem $\mathrm{Cy}$ cles 9:23-36. doi: 10.1029/94GB02723

Raich JW, Schlesinger WH (1992) The global carbon dioxide flux in soil respiration and its relationship to vegetation and climate. Tellus 44B:81-99

Raich JW, Potter CS, Bhagawati D (2002) Interannual variability in global soil respiration, 1980-94. Glob Change Biol 8:800-812. doi: 10.1046/j.1365-2486.2002.00511.x

Risk D, Kellman L, Beltrami H (2002a) Carbon dioxide in soil profiles: production and temperature dependence. Geophys Res Lett 29:11-1-11-4

Risk D, Kellman L, Beltrami H (2002b) Soil $\mathrm{CO}_{2}$ production and surface flux at four climate observatories in eastern Canada. Global Biogeochem Cycles 16. doi: 10.1029/2001GB001831

Riveros-Iregui DA, Emanuel RE, Muth DJ et al (2007) Diurnal hysteresis between soil temperature and soil $\mathrm{CO}_{2}$ is controlled by soil water content. Geophys Res Lett 34:L17404. doi: 10.1029/2007GL030938,2007

Riveros-Iregui DA, McGlynn BL, Epstein HE, Welsch DL (in press) Interpretation and evaluation of combined measurement techniques for soil $\mathrm{CO}_{2}$ efflux: discrete surface chambers and continuous soil $\mathrm{CO}_{2}$ concentration probes. J Geophys Res Biogeosci. doi: 10.1029/2008JG000811

Robinson DA, Jones SB, Wraith JM et al (2003) A review of advances in dielectric and electrical conductivity measurements in soils using time domain reflectometry. Vadose Zone J 2:444-475

Schadt CW, Martin AP, Lipson DA, Schmidt SK (2003) Seasonal dynamics of previously unknown fungal lineages in tundra soils. Science 301:1359-1361. doi: 10.1126/science.1086940

Schlesinger WH (1997) Biogeochemistry: an analysis of global change. Academic Press, San Diego

Scott-Denton LE, Sparks KL, Monson RK (2003) Spatial and temporal controls of soil respiration rate in a high-elevation, subalpine forest. Soil Biol Biochem 35:525-534. doi: 10.1016/S0038-0717(03)00007-5

Sjogersten S, van der Wal R, Woodin SJ (2006) Small-scale hydrological variation determines landscape $\mathrm{CO}_{2}$ fluxes in the high Arctic. Biogeochemistry 80:205-216. doi: 10.1007/s10533-006-9018-6

Skopp J, Jawson MD, Doran JW (1990) Steady-state aerobic microbial activity as a function of soil water content. Soil Sci Soc Am J 54:1619-1625

Sommerfeld RA, Massman WJ, Musselman RC (1996) Diffusional flux of $\mathrm{CO}_{2}$ through snow: Spatial and temporal variability among alpine-subalpine sites. Global Biogeochem Cycles 10:473-482. doi: 10.1029/96GB01610

Tang J, Baldocchi DD, Qi Y, Xu L (2003) Assessing soil $\mathrm{CO}_{2}$ efflux using continuous measurements of $\mathrm{CO}_{2}$ profiles in soils with small solid-state sensors. Agric For Meteorol 118:207-220. doi: 10.1016/ S0168-1923(03)00112-6

Washington JW, Rose AW, Ciolkosz EJ, Dobos RR (1994) Gaseous diffusion and permeability in four soil profiles in central Pennsylvania. Soil Sci 157:65-76. doi: 10.1097/00010694-199402000-00001

Welles JM, Demetriades-Shah TH, McDermitt DK (2001) Considerations for measuring ground $\mathrm{CO}_{2}$ effluxes with chambers. Chem Geol 177:3-13. doi: 10.1016/ S0009-2541(00)00388-0

Welsch DL, Hornberger GM (2004) Spatial and temporal simulation of soil $\mathrm{CO}_{2}$ concentrations in a small forested catchment in Virginia. Biogeochemistry 71:415436. doi: 10.1023/B:BIOG.0000049350.24911.e9 Wilson DJ, Western AW, Grayson RB (2005) A terrain and data-based method for generating the spatial distribution of soil moisture. Adv Water Resour 28:4354. doi: 10.1016/j.advwatres.2004.09.007

Woods SW, Ahl R, Sappington J, McCaughey WW (2006) Snow accumulation in thinned lodgepole pine stands, Montana, USA. For Ecol Manag 235:202-211. doi: 10.1016/j.foreco.2006.08.013 